\title{
CHOICES AND CONSEQUENCES: IMPACT OF MOBILITY ON RESEARCH-CAREER CAPITAL AND PROMOTION IN BUSINESS SCHOOLS
}

\author{
OLGA RYAZANOVA \\ PETER MCNAMARA \\ Maynooth University, Maynooth, County Kildare, Ireland
}

\begin{abstract}
We focus on the role that domestic and international mobility play in achieving a business academic's career outcomes. We seek to advance existing research by taking a morenuanced approach to the study of mobility. Using a sample of 376 tenured faculty members from 20 highly research-visible European business schools in 10 countries, we explore different patterns of mobility and highlight their link to research-career capital and the speed of academic promotion. Our findings show that mobility has a positive impact on research-career capital, but multiple moves delay academic promotion. In making decisions about international mobility, it is important to know that moving internationally for one's first post-PhD job undermines research productivity. However, moving internationally between year 2 and year 7 post-PhD is better than moving later on. The ability to move between countries is deeply rooted in gender, with female faculty less likely to access international mobility. Female academics also take longer to be promoted to a tenured rank and to full professorship. Our findings have implications for academic researchers who consider domestic and international mobility, and for $\mathrm{PhD}$ supervisors whose duty it is to prepare their students for successful careers in academia.
\end{abstract}

We explore the career journeys of tenured European business-school faculty and the role that mobility played both in the accumulation of their researchcareer capital and in the speed of academic promotion. Research-career capital, which we define here as one's portfolio of peer-reviewed publications, is fundamental for sustaining academics' identity as researchers (Day, 2011; Knights \& Clarke, 2014). Academic promotion brings rewards in the form of personal career stability and additional resources. Both have value for individuals.

The idea that academics should behave strategically in their career choices has become increasingly prominent in career research (Dowd \& Kaplan, 2005;

We wish to thank our Action Editor Tine Köhler and three anonymous reviewers who have provided constructive and useful feedback that helped develop this paper for publication. We also thank our graduate student, Adam Keeley, who assisted with some aspects of the data-collection process. We are also grateful to our colleague, Marian Crowley-Henry, for her comments on an early draft of this paper. An early version of the paper was presented at the Management Education and Development (MED) division of the Academy of Management and received the division's Global Forum Award in 2018. We are grateful to MED community of reviewers and participants for their feedback and their support of our work.
Lamb \& Sutherland, 2010). The central theme of career research is that career choices should deliver valuable performance outcomes that include (but are not limited to) volume, visibility, and impact of scholarly publications (Callie \& Cheslock, 2008). Prior empirical research has offered a variety of strategies for influencing publication outcomes, for example, choosing productive supervisors at the start of one's academic career (Gu, Lin, Vogel, \& Tian, 2011; Hilmer \& Hilmer, 2007) and building coauthorship networks later (McFadyen \& Cannella, 2004; Ryazanova \& McNamara, 2016).

Academic mobility is promoted as another way to achieve research productivity because it is associated with scientific collaboration, training, and knowledge-sharing (Jonkers \& Cruz-Castro, 2013; Veugelers \& Van Bouwel, 2015). However, mobility can disrupt work patterns and social networks, and often comes with a cost to personal life, especially in the case of international mobility (Oliver, 2012; Richardson \& Zikic, 2007). The potential costbenefit ratio might vary for different career outcomes, such as research-career capital and academic promotion. Therefore, the impact of mobility on career outcomes requires thorough investigation.

We explore several subquestions to address different aspects of mobility choices and consequences. 
First, if one wants to use domestic or international mobility as a career development strategy, what is the relationship between early-career factors and mobility? Second, how does the timing of international mobility influence long-term research outcomes? Third, what are the performance consequences of moving in "large leaps" between institutions of very different standing? Fourth, how do domestic and international mobility influence the speed of academic promotion?

Mobility, defined as combinations of changing employers and changing countries with the intention of establishing or re-establishing an academic home, has the potential to support and enhance research-career capital in a variety of ways. For academics employed by research-visible institutions (institutions producing large amounts of research in international peer-reviewed outlets), international mobility can strengthen the global visibility of their research by exposing scholars to a variety of perspectives and helping them deliver globally relevant insights (De Meyer, 2012). For academics employed in less prominent institutions, mobility might bring resources lacking in their current workplace. Although there is strong evidence that research-career capital is driven by individual agency (Miller, Taylor, \& Bedeian, 2011; White, James, Burke, \& Allen, 2012), the literature also emphasizes the role of the organizational environment in supporting research productivity (e.g., Bedeian, Cavazos, Hunt, \& Jauch, 2010; Smeby \& Try, 2005). The majority of business school faculty are not employed by elite research institutions, where the environment is particularly beneficial for growing a research portfolio (Hommel \& Thomas, 2014; Marx, Garcia, Butterfield, Kappen, \& Baldwin, 2016). Therefore, it is important to understand whether mobility has a sufficiently strong independent effect on research-career capital to compensate for the differences in organizational environment.

The influence of mobility, and international mobility in particular, on the speed of academic promotion is another key question, the answer to which is complex. Although research productivity often takes center stage in promotion decisions (Lissoni, Mairesse, Montobbio, \& Pezzoni, 2011), other roles played by faculty are also considered. Mobility might influence speed of promotion by providing academics with experiences and capabilities desired by employers in addition to, or separate from, research productivity. However, mobility might also delay promotion by interfering with teaching and administration duties, which tend to be more institutionspecific than research.
Our study uses data from a multicountry sample of tenured faculty working in some of the most research-visible business schools in Europe to offer evidence-based advice to the new generation of doctoral students and early-career faculty, helping to inform their career choices. Traditionally, European business schools have "possessed a strong international mindset" (Thomas, Lorange, \& Sheth, 2013: 34 ). This is partly driven by one of the four fundamental freedoms of the European Union (EU); namely, free movement of persons. EU citizens can move freely between member states to live, study, and work, encouraging student and faculty mobility. Therefore, European business schools are a representative environment where international mobility is actively supported and widely practiced (Børing, Flanagan, Gagliardi, Kaloudis, \& Karakasidou, 2015; Morano-Foadi, 2005; Oliver, 2012).

Here we seek to advance two research streams: First, we contribute to research that seeks to inform career guidance as part of doctoral education in business schools (e.g., Bedeian et al., 2010; Ryazanova \& McNamara, 2016). Although studies have addressed the development of relevant research skills in doctoral programs (Aitchison, 2009; Boud \& Lee, 2005; Corner \& Pio, 2017), the preparation of $\mathrm{PhD}$ students for labor markets is a relatively underdeveloped area of management education literature and is often included as an afterthought in the studies of doctoral students' experience (e.g., McAlpine, Amundsen, \& Turner, 2014). We demonstrate which components of early-career capital need to be developed to improve $\mathrm{PhD}$ graduates' access to mobility. We also explore the link between mobility (and international mobility specifically) and the speed of academic promotion, enabling $\mathrm{PhD}$ graduates to make an informed decision on the consequences of mobility. Second, we add to the literature on international mobility in academic careers (e.g., Cruz-Castro \& Sanz-Menendez, 2010; Richardson, 2009) by identifying the patterns of post-PhD mobility that are more likely to improve research-career capital.

\section{CONCEPTUAL BACKGROUND}

The phenomenon of interorganizational mobility in academia has been of interest to several research streams. Studies in sociology of science and in scientometrics have explored how mobility is related to scientific outcomes (e.g., Allison \& Long, 1990; Fernández-Zubieta, Geuna, \& Lawson, 2015) and to the individual career experiences of academics 
(e.g., Johansson \& Śliwa, 2014; Oliver, 2012). Career researchers have discussed whether academic careers can serve as a representative example of protean or "boundaryless" careers (Baruch \& Hall, 2004; Dany, Louvel, \& Valette, 2011). More recently, research on self-initiated expatriates (Doherty, 2013) has used internationally mobile academics as typical examples of professionals driven by their own career ambitions to move abroad.

\section{International Mobility in Business Schools}

At the faculty level, "a large number of researchers moved from Europe to the US in the post-war era" (Kamalski \& Plume, 2013: 30). At the student level, millions of students moved back and forth between less developed countries and universities abroad, supporting the adoption of Western models of higher education globally (Altbach, 1991; Geiger, 1990, 1997). Historically, faculty mobility was the prerogative of elite researchers and institutions (Laudel, 2005). Now, faculty other than international elites are more likely to have internationally mobile academic careers (Børing et al., 2015).

Three key reasons have driven this shift in career trajectories. First, demand for international faculty has increased. Many business schools aspire to serve the needs of a globalized economy (Mendenhall, Arnardottir, Oddou, \& Burke, 2013) and are motivated to attract faculty with international capabilities to teach increasingly international student cohorts (Lichy \& Pon, 2015). This motivation may come from employers, students themselves, or international accreditors (Schworm, Cadin, Carbone, Festing, Leon, \& Muratbekova-Touron, 2017). For example, the European Foundation for Management Development, the official body behind EQUIS accreditation, argues that "an overall framework for defining and implementing an internationalisation strategy will have to include target markets, programme portfolio, faculty profile, governance and management and last but not least strategic alliances" (Plompen, 2013). Similarly, the Association to Advance Collegiate Schools of Business highlights the importance of internationalization in business schools and calls for "cultivating a global mindset among faculty, staff, and students" (AACSB International, 2011: 223).

Second, financial, legal, and cultural support for mobility has improved. Multiple initiatives aim to facilitate the mobility of individual scientists, such as the Fulbright Program in the United States (Kahn \& MacGarvie, 2012) or the Erasmus and Marie Curie programs in Europe (Morano-Foadi, 2005; Oliver, 2012). Third, the increasing use of standardized research metrics has made it easier for researchers from non-elite institutions to signal their capabilities to employers abroad (Van den Brink, Fruytier, \& Thunnissen, 2013).

Although narrowing the definition of research capability to measurable publication outcomes is condemned by many academics who started their careers under a different understanding of what "academic life" is (e.g., Mingers \& Willmott, 2013; Willmott, 2011), for new generations of academics, this approach is a fact of life. For those who started their career journeys recently or are going to enter the academic market in the near future, the definition of research-career capital based on measurable publication outcomes is firmly embedded in the dominant logics of our industry. Not all career decisions made by academics are driven by the need to develop a research portfolio (Siekierski, Lima, \& Borini, 2018). Other roles as educators or administrators play their part in career choices (Janger \& Nowotny, 2016). Nonetheless, academics should be aware of the consequences of these choices.

\section{Mobility and Early-Career Capital of Academics}

We start our exploration of the factors influencing access to mobility with a brief summary of what we know so far about academic mobility. The extant literature seeks to answer three broad questions: (1) Why do academics move jobs and what makes a job elsewhere attractive for them? (2) What facilitates (or impedes) academic mobility between organizations and countries? (3) What are the consequences of mobility for individual academics, the organizations that hire them, and the countries from which they move?

Answering the first question, the literature identifies push factors, such as the lack of jobs at home (Morano-Foadi, 2005), and pull factors, such as the desire for new cultural experiences (Richardson \& Zikic, 2007), the higher quality of life in another country, and the higher quality of peers elsewhere (Azoulay, Ganguli, \& Zivin, 2017; Janger \& Nowotny, 2016). Jobs that are attractive to research-active academics satisfy "taste for science" and offer a moderate teaching load, autonomy in research, a good salary, and research funding (Janger \& Nowotny, 2016). Country-level factors are more important than organizational factors in attracting researchers from abroad (Lepori, Seeber, \& Bonaccorsi, 2015). That said, academics' decision-making about 
mobility is not necessarily rational. Research on the motivations of self-initiated expatriates, including the studies set in academia, shows that career advancement is just one of many reasons why they move between countries (Doherty, 2013; Richardson \& Zikic, 2007).

Answering the second question, researchers found that prior experience of international mobility (e.g., during student years) makes academics more likely to move (Børing et al., 2015; Equeter \& Hellemans, 2016) as a result of both reduced uncertainty about what it might entail and a better understanding of the potential benefits. Highly productive academics are more likely to move (Azoulay et al., 2017); the volume of recently published research, rather than its impact, seems to enable mobility (Allison \& Long, 1987; Edler, Fier, \& Grimpe, 2011).

In exploring the enablers of international mobility, current literature does not pay sufficient attention to early-career factors that lead to internationally mobile careers. Consequently, it fails to provide guidance for doctoral students and their supervisors on how best to prepare for such careers. Academic careers have a path-dependent nature (Bedeian et al., 2010; Miller, Glick, \& Cardinal, 2005), which can only partly be alleviated by proactive behavior at later career stages (Ryazanova \& McNamara, 2016). Therefore, understanding in earlier career stages what the options are for accessing international mobility is vital for the socialization of doctoral students into the new rhythms of academic life.

The literature highlights research visibility of doctoral origin ${ }^{1}$ (Bedeian et al., 2010; Debackere \& Rappa, 1995) and early-career productivity (Park \& Gordon, 1996; Williamson \& Cable, 2003) as key early-career factors that drive academic career trajectories. Extending these insights to the study of internationally mobile academic careers, we argue that graduates of doctoral schools with high research visibility and graduates with stronger early-career performance (volume and/or visibility of publications) should have better access to job opportunities abroad.

H1: Early-career capital is positively related to mobility (both domestic and international).

Studies exploring the barriers to mobility found that gender and caring commitments play significant roles in mobility decisions (Tharenou, 2008). Female academics move less often (Børing et al., 2015;

\footnotetext{
1 "Doctoral origin" is defined as the institution where individuals obtain their $\mathrm{PhD}$ degrees.
}

Welch, 1997) and have a higher threshold for mobility. If they move at all, they are more likely than men to move up (to a better quality workplace) rather than laterally (Azoulay et al., 2017). Academics with children in high school (ages 14-17) are less likely to move because they are unwilling to uproot their teenagers during such an important stage of their lives. This effect, again, is more pronounced for female academics (Azoulay et al., 2017).

Within the context of international mobility, qualitative studies of academics' careers reveal the personal cost of moving between countries where a spouse could not subsequently find employment (e.g., Oliver, 2012; Richardson \& Zikic, 2007). This cost is particularly high for female academics, who must work against the stereotypes that a female partner should support her male partner's career (rather than disrupt it) and that a male partner's worth is defined by his ability to be a breadwinner (which might be challenging after the move). Sang and colleagues' (2013) study of migrant female professors found that their main reason for mobility was to follow the male partner. Studies also show that, relative to their male peers, female academics rarely enjoy the luxury of having a non-employed supportive spouse (Baker, 2010) and are more often primary caregivers for children and elderly parents (Johansson \& Śliwa, 2014).

H2: Ceteris paribus, female academics are less likely to be mobile (both within the domestic market and internationally).

\section{International Mobility and Research-Career Capital}

In answering the question about the consequences of international mobility, Equeter and Hellemans (2016) found that it leads to higher work engagement and employee well-being. Numerous studies of academic productivity also found that, although international mobility brings a decrease in performance in the short term (Bäker, 2015; FernándezZubieta et al., 2015), it is positively related to research productivity in the long term (Veugelers \& Van Bouwel, 2015; Zubieta, 2009). More specifically, it was found that international mobility is positively correlated to the number of citations (Halevi, Moed, \& Bar-Ilan, 2016) and the likelihood of producing frequently cited papers (Yamashita \& Yoshinaga, 2014). For researchers in non-English-speaking countries, international mobility brings an increase in the number of publications in international journals, as found by Jonkers and Cruz-Castro (2013) in Argentina 
and by Gavrilova et al. (2015) in Russia. International researchers who can leverage home-country linkages after the move achieve higher productivity (Baruffaldi \& Landoni, 2012).

H3: Mobility (domestic and international) mediates the relationship between early-career capital and long-term research-career capital.

\section{Patterns of Mobility and Research-Career Capital}

As discussed earlier, existing research has created an awareness among business school faculty that mobility might generally benefit their careers. This does not necessarily mean that academics have an understanding of the most productive patterns of such mobility. We seek to advance existing research by taking a more nuanced approach to the study of mobility and its influence on research productivity. So far, the studies of mobility have not focused on the timing of mobility and on the difference between workplaces in an academic's career trajectory. We fill this gap by exploring whether the timing of international mobility matters for long-term research outcomes (volume and impact of research), and whether moving in "large leaps"-in what we call the radical step mobility pattern-between institutions of very different standing brings superior or inferior results compared to more conservative mobility patterns.

The tradition of early-career mobility is well established in life sciences, where postdoctoral positions are considered to be an essential component of an academic career. There is evidence that international postdoctoral mobility has a positive impact on performance by enabling the formation of weak ties (Yang \& Webber, 2015; Zubieta, 2009). Traditionally, postdoctoral mobility has been rare in business schools; however, it has become more widespread due to the lack of tenure-track positions available for doctoral program graduates (Bloch, Graversen, \& Pedersen, 2015; Huisman, de Weert, \& Bartelse, 2002). We focus here on another type of early-career mobility: International mobility which occurs immediately after $\mathrm{PhD}$, when graduates relocate from the country of doctoral origin to another country for their first full-time faculty position. Such a move enables recent graduates to build a professional identity independent of their $\mathrm{PhD}$ advisor and to form networks beyond the local ties of their doctoral origin. Early-career faculty do not usually have many coauthors (except advisors). Moving helps build new connections, creating productive opportunities, albeit at the cost of some disruption to existing networks.

H4: Moving internationally immediately after PhD is associated with higher research-career capital.

Literature about the research productivity of earlycareer scholars emphasizes the challenges encountered in the first few years as a tenure-track faculty member, such as the lack of time for research due to settling into the new role of an educator (Marx et al., 2016; Miller et al., 2011; White, Carvalho, \& Riordan, 2011). These challenges can be magnified if academics who found their first job abroad decide to continue moving internationally before achieving the relative stability of a tenured position. Although the skill of publishing research in English-language journals may be transferable across international borders, administration duties are highly institutionspecific, and teaching is often location- and culturespecific. Therefore, each international move requires new service-related knowledge and an adjustment of one's teaching portfolio, increasing pressure on already time-starved tenure-track academics. Moving at this stage might also disrupt existing coauthorship networks, with a detrimental effect on research productivity. This is not to say that the benefits of mobility might not re-emerge at a later career stage, when academics are not working against the tenure clock.

H5: International mobility at an early stage in an academic career (other than mobility for one's first full-time faculty position) is negatively related to research-career capital.

Differences between the old workplace and the new workplace can also influence research productivity. Academics who make radical leaps up or down the visibility hierarchy face very different environments, which can lead to difficult career adjustments or bring extraordinary rewards. Academics who make a radical leap up can reach beyond the boundaries and capabilities of national elites (Gibson \& McKenzie, 2014). However, to make such a leap, academics must demonstrate extraordinary research productivity to compensate for the lack of institutional prestige of their doctoral origin. It is likely, therefore, that these academics are highly intrinsically motivated to conduct research despite the lack of research culture in their previous workplace (White et al., 2012). Moving upward along this continuum requires a continued commitment to research productivity at a level above the requirement of the current workplace. This is only possible where individual agency (namely, intrinsic motivation to 
conduct research) is stronger than organizational career scripts. Prior studies showed that intrinsic motivation is one of the most important drivers of research productivity (Miller et al., 2011; White et al., 2012). Combining this strong motivation with the superior research capabilities of a new workplace delivers strong research outcomes. Academics who make a radical leap down might be able to exploit a "big fish in a little pond" effect and acquire "star" status in a new workplace. Although the research capabilities of a new workplace are likely to be inferior to their previous workplace, their personal level of research support might be superior due to "i-deals" (idiosyncratic employment arrangements) that star employees are often able to negotiate for themselves (Aguinis \& O’Boyle, 2014). Upon securing those i-deals, the new hires are under pressure to prove their value to a new employer (Pazzaglia, Flynn, \& Sonpar, 2012), which motivates productivity.

H6: Radical step mobility has a positive relationship with research-based career capital, both in the case of upward mobility and in the case of downward mobility.

Seen as a career strategy, mobility is, fundamentally, a process of searching for the best fit between the quality of a workplace environment and one's career-capital ambitions. One of the fundamental assumptions of the recruitment literature is that "individuals seek a work organization where they can fulfil their goals" (Porter, Hackman, \& Lawler, 1975: 131, cited in Bangerter, Roulin, \& König, 2012). Although some employees are able to achieve this fit after the first move, others move several times before reaching a suitable workplace. Translated into academia, one core aspect of this "fit search" is the development of publication performance that enables further mobility. In addition, each move exposes an academic to new knowledge and brings opportunities for expanding professional networks and sharing their research insights with a new community of colleagues. Although H5 (stated above) emphasizes the importance of stability at the formative stage of an academic career, H7 (below) addresses the effect of mobility choices over the entire academic career.

H7: The number of inter-organizational moves throughout an academic career is positively associated with research-career capital.

\section{Mobility and Academic Promotion}

What influences an academic's chances of being promoted to a tenured position or full professorship? The literature agrees on the importance of research productivity (Parker, 2008; Van den Brink et al., 2013) but also highlights the role of teaching performance (Parker, 2008), institutional and scientific leadership, and professional networks (Baker, 2010).

A number of studies found that foreign-born academics often outperform domestic faculty in research (Libaers, 2007; Mamiseishvili, 2010). Qualitative studies of internationally mobile academic careers provide some insights about the reasons for this productivity. First, academics hired from abroad often face challenges in teaching and academic service due to language and cultural barriers and lack of in-depth knowledge of local contexts. This makes it more difficult for them to engage with students and colleagues, perform pastoral duties, and navigate intra-organizational politics (Johansson \& Śliwa, 2014; Pherali, 2012). Domestic faculty may resent having to shoulder more of these duties, preventing them from delivering research outcomes comparable to international faculty. Meanwhile, international faculty feel that they need to outperform their domestic colleagues to justify the extra effort that the institution put into hiring from abroad (Fernando \& Cohen, 2016). Worth mentioning is that return mobility for some academics is problematic due to the loss of connections with domestic academic gatekeepers who control access to academic careers (Morano-Foadi, 2005). Consequently, international faculty prioritize publishing and research income generation over other academic activities (Fernando \& Cohen, 2016; Mamiseishvili, 2010; Webber, 2012).

The answer to the question about whether mobility in general, and international mobility in particular, necessarily translates into career success in terms of permanent positions and academic ranks is less clear. On the one hand it brings an increase in research-career capital, which is traditionally considered to be the key driver of promotion. Mobility also gives academics a better understanding of the local and global competitive environment, which is particularly valuable for promotion to full professorship. Female academics who decided to be mobile were better represented in higher ranks than non-mobile ones (Welch, 1997).

On the other hand, teaching and service are important aspects of an academic job, and mobility disrupts both of them. There is also some evidence that non-mobile academics enjoy more stable careers and predictable promotion patterns (Cruz-Castro \& Sanz-Menendez, 2010). This evidence is, however, based on single-country samples; therefore, it is worth exploring whether there is a trade-off between 
having a domestically or internationally mobile career and getting promoted earlier in one's career.

H8a: Academics who move more often in their careers (domestically or internationally) receive promotion to associate professor or senior lecturer level (levels traditionally associated with permanent or tenured positions) later in their careers, relative to their nonmobile peers.

H8b: Academics who move more often in their careers (domestically or internationally) receive promotion to full professorship later in their careers, relative to their non-mobile peers.

Our conceptual model is presented in Figure 1.

\section{METHODS}

\section{Sample and Data Collection}

Our sampling approach is based on several criteria. First, we focused on settings where long-term mobility is a common feature of academic careers (Børing et al., 2015). This led to the choice of European business schools as the broad sampling population. Second, within this setting we needed to focus on organizations where faculty were strongly motivated to publish research in international peer-reviewed journals, and where a research portfolio was core to academics' career capital. Following this logic, we searched for the most research-visible European business schools.

At the time of data collection, there was no readily available league table that would enable us to identify those schools. Although in the United States (US) scholars can use (with some caveats) the Carnegie Classification of Institutions of Higher Education, including colleges and universities, in the multicountry context of the European business education field a similar metric was missing. Financial Times rankings are widely used by students to assess the relative quality of European MBA and master's programs. The mass media rankings, however, have limited construct validity when it comes to comparing the visibility of business schools in the research community because the majority of scores in these rankings are based on surveys of students and other metrics unrelated to research. For example, "weighted salary" and "salary increase" measures together contribute $40 \%$ to the Financial Times Global MBA ranking score (Ortmans, 2015), and student satisfaction accounts for $45 \%$ of the Bloomberg Businessweek ranking (Rodkin, 2014).

FIGURE 1

Conceptual Model. $\mathrm{IM}=$ international move.

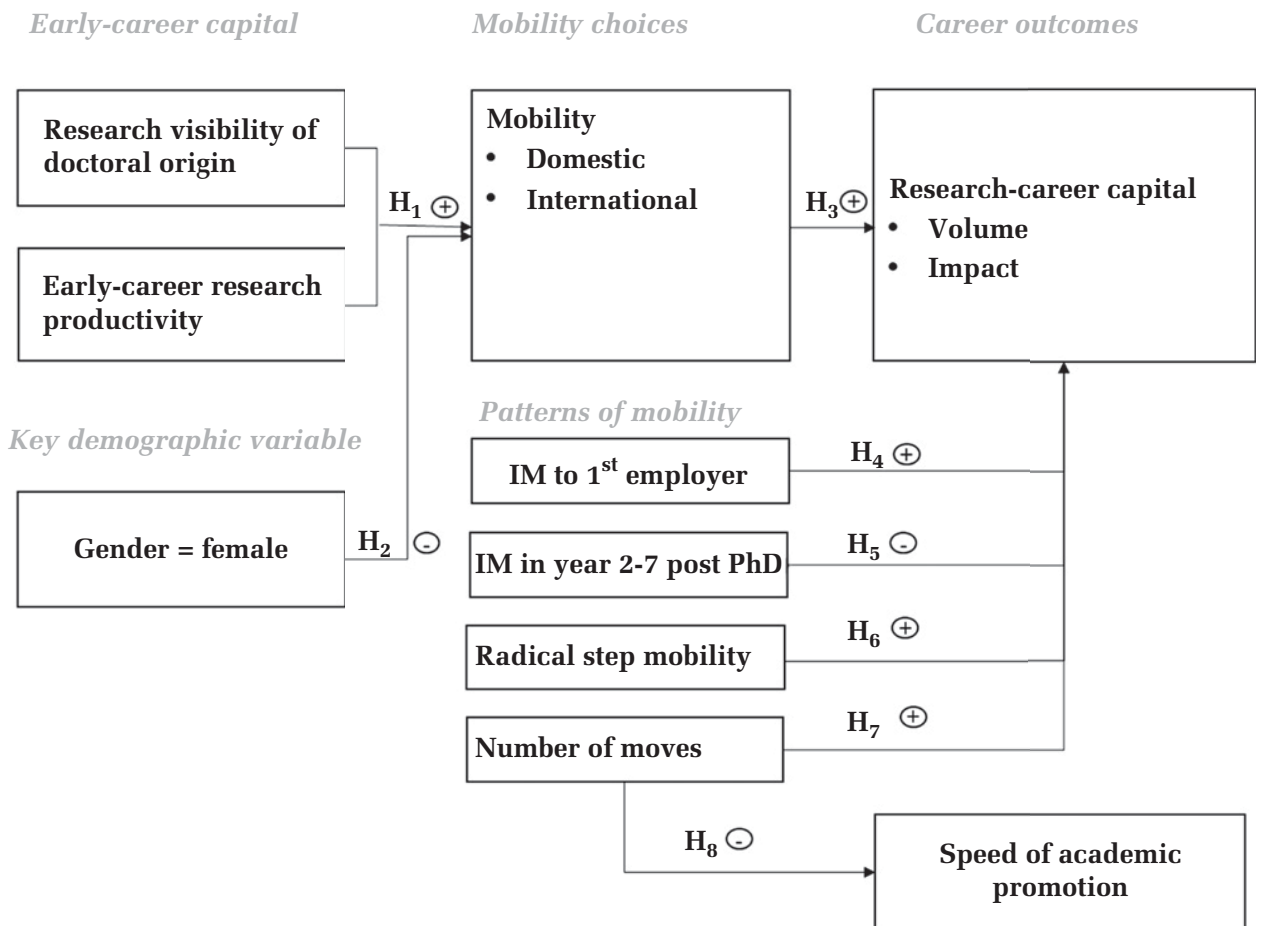


To tackle this measurement issue, we built upon prior scientometric research (Mangematin \& BadenFuller, 2008) and developed a metric of research visibility based on institutions' publications in the top-150 journals in the InCites Journal Citations Reports, produced in the period 2007-2012. The journals were taken from the Business, Business Finance, Management, and Public Administration categories. These broad categories include the majority of journals in which business school faculty are likely to publish. Our metric takes the number of published papers and weights it by the impact factor of the journal in which each paper was published.

We then ranked all European business schools according to this metric of research visibility and selected the top-50 as our sampling frame. In line with prior studies (e.g., Baden-Fuller, Ravazzolo, \& Schweizer, 2000) we included in the sampling frame any schools ranked within the top-50 and located in countries that enjoy the status of associated countries under the European Commission Framework Program for Research and Innovation. These countries include Israel, Turkey, Switzerland, Norway, Iceland, and a range of Eastern European countries (European Commission, 2014).

Mindful of the need to collect nuanced longitudinal data on academics' career journeys, other factors that might influence career capital, and our own resource limitations, we limited our sample to 20 schools, randomly selected from our sampling frame. To ensure that our sampled schools did not differ in a systematic way from the rest of the schools in the top-50 list, we compared the research visibility of business schools across the two groups. No significant differences were found. Sampled and nonsampled schools represent a similar number of countries, and their country coverage shows $60 \%$ overlap. From each school we selected the same number of faculty to avoid possible bias from large schools dominating the sample.

Our third criterion addresses individual academics' career stage. We opted to include only tenured faculty in our sample, that is, those who had reached the rank of senior lecturer, associate professor, reader, or full professor. Our choice of tenured faculty was based on two reasons: one conceptual and one pragmatic. Conceptually, academics who have passed the tenure threshold have proven to their institutions that they satisfy criteria set out for research-active faculty. It can be argued that some research-visible schools would not hire a $\mathrm{PhD}$ graduate if they had not demonstrated that they could satisfy such criteria. However, it is possible that the promise of strong research capability shown in a graduate's résumé at the time of hiring is not then realized to an extent sufficient to grant tenure. After all, the academic profession is full of rejections (Day, 2011). A study by Certo et al. (2010) found that it takes more than 5 years to publish the number of papers required for promotion to tenure position in top schools, which undermines the chances for promotion for many academics. Where a tenuretrack academic has been hired from outside the organization (or from abroad), it is possible that the promise of research capability is not realized due to the costs of inter-organizational (or international) mobility. From a pragmatic point of view, our data did not allow us to distinguish clearly between tenure-track and nontenure-track (teaching only) academics. Both categories could be listed as "lecturers" or "assistant professors" in faculty directories.

For each of the 20 sampled schools we collected full lists of tenured faculty from the schools' websites. Adjunct, part-time, visiting, emeritus faculty, and faculty without a $\mathrm{PhD}$ were excluded. From the population of tenured faculty within each school we randomly selected 20 academics. Again, this choice was driven by the need to find a balance between a nuanced exploration of careers and our own resource limitations. Sometimes, the number of tenured academics for whom necessary career information (e.g., the school of $\mathrm{PhD}$ ) was available was less than 20; in such cases we included all academics for whom the data were available. We sought to maintain the proportion of male and female faculty typical for each school, calculated by counting the number of male and female academics in the full list of tenured faculty. Our final sample is, therefore, a stratified random sample. The summary of the sample is presented in Table 1.

Publication data for the full career span of each academic up to September 2018 were collected using Thomson Reuters ISI Web of Science. Web of Science is traditionally considered to be the "gold standard" for bibliometric analysis (Harzing \& Alakangas, 2016).

For each selected academic we collected career data from résumés available on business school websites. We used the ProQuest Database of Dissertations and Theses, the Index to Theses database, and, occasionally, LinkedIn profiles to fill the gaps in career data. The use of résumés is an established methodology in academic career research (e.g., Cañibano \& Bozeman, 2009). The benefits of using résumés published on business schools' websites 
TABLE 1

Summary of the Sample

\begin{tabular}{|c|c|c|c|}
\hline University & $\begin{array}{l}\text { Number of Academics } \\
\text { Sampled }\end{array}$ & $\begin{array}{c}\text { Male } \\
\text { Academics }\end{array}$ & $\begin{array}{l}\text { Female } \\
\text { Academics }\end{array}$ \\
\hline 1. Aalto University, Finland & 20 & 14 & 6 \\
\hline 3. City University London, Cass Business School, UK & 20 & 18 & 2 \\
\hline 4. Erasmus University, the Netherlands & 20 & 18 & 2 \\
\hline 5. ETH Zurich, Switzerland & 17 & 16 & 1 \\
\hline 8. INSEAD, France & 20 & 17 & 3 \\
\hline 9. London Business School, UK & 20 & 18 & 2 \\
\hline 10. SDA Bocconi University, Italy & 20 & 14 & 6 \\
\hline 11. Tel Aviv University, Israel & 20 & 16 & 4 \\
\hline $\begin{array}{l}\text { 12. London School of Economics and Political } \\
\text { Science, University of London, UK }\end{array}$ & 15 & 10 & 5 \\
\hline 17. University St. Gallen, Switzerland & 20 & 18 & 2 \\
\hline 18. University of Strathclyde, UK & 20 & 14 & 6 \\
\hline 19. Utrecht University, the Netherlands & 20 & 14 & 6 \\
\hline $\begin{array}{l}\text { 20. WHU Otto Beisheim School of Management, } \\
\text { Germany }\end{array}$ & 10 & 9 & 1 \\
\hline Total & 376 & 303 & 73 \\
\hline
\end{tabular}

and information from databases such as ProQuest are twofold: First, these résumé data are validated by the institutions that publish them. This reduces potential self-enhancement biases that might appear in the survey data. Second, this methodology ensures that the study can be replicated by other scholars, because even web pages that are no longer active could be retrieved through the Internet archive project Wayback Machine.

\section{Variables}

Career outcome variables. Our study explores two sets of career outcome variables. Career outcome variables that measure research-career capital are defined in terms of volume and scholarly impact of research output. We used the number of ISI-visible publications and the number of citations accumulated by each individual in our sample by 2018 . Both variables were winsorized at the top $5 \%$ to exclude possible bias due to the presence of outliers in the data.

Career outcome variables that measure speed of academic promotion include, first, time to tenure, measured as the number of years between $\mathrm{PhD}$ graduation and promotion to the rank of senior lecturer or associate professor. Where promotion to a reader position or full professorship happened directly after a lecturer or assistant professor position, the time of this promotion was considered as the time of getting tenure. The second academic promotion variable is time to full professorship, measured as the number of years between $\mathrm{PhD}$ graduation and promotion to the rank of full professor.

Early-career capital variables. Looking at the initial conditions that enable international mobility, we explore visibility of doctoral origin and earlycareer research productivity as key potential drivers of one's ability to move abroad. Visibility of doctoral origin was measured as the research visibility of the $\mathrm{PhD}$ institution, using the weighted volume of research metric provided by the Global Research Performance Database (Ryazanova, McNamara, \& Aguinis, 2017). This metric captures publications in the period 2007-2015 and weights these by the 5year impact factor of the journals where each paper was published.

We used two metrics of early-career publication outcomes to measure early-career research productivity: the number of ISI-visible publications (papers, book chapters, and proceedings papers) published by the end of the 3rd year post-PhD and the average 5-year impact factor (2017 issue) of the journals where these early-career publications 
appeared. On average, it takes $2-3$ years to publish a paper in a peer-reviewed journal: therefore, research productivity by the end of the 3rd year post-PhD should be a good proxy for the early-career pipeline that employers would see in a recent $\mathrm{PhD}$ graduate's résumé.

Demographics. Gender was coded as 0 for female academics and as 1 for male academics.

Mobility variables. Mobility was measured as a categorical variable, coded 0 for non-mobile careers, 1 for careers with domestic mobility only, and 2 for internationally mobile careers. This variable was used as a dependent variable for testing Hypotheses 1 and 2. In testing H3 and H8 we also used binary variables for domestic and international mobility. Separately, we totaled the number of times an academic moved jobs (number of moves). This variable was used in testing Hypotheses 7 and 8.

The timing of international mobility was captured by two variables: International mobility (IM) to first employer is a binary variable coded as 1 if an academic moved countries immediately post-PhD; International mobility (IM) in years $2-7$ post-PhD is a binary variable coded as 1 if an academic moved between countries between the 2nd and the 7th year post-PhD. This time period was chosen to represent the standard length of a tenure-track period. Robustness checks with a cut-off point of Year 5 instead of Year 7 showed that the findings remain consistent for both measurement approaches. Radical step mobility is a binary variable coded as 1 if an academic moved to a school with research performance (measured using the weighted volume metric from the Global Research Performance Database, as described earlier) more than two times higher or lower than their previous workplace at least once in their career, and 0 otherwise.

Control variables. We control for other factors that might influence career capital and academic promotion by including a number of demographic variables, such as professional age and discipline area. Professional age is measured as the number of years since $\mathrm{PhD}$. Discipline area is a categorical variable coded on the basis of résumé data and includes accounting, economics, finance, management information systems (MIS), management, marketing, organizational behavior (OB)/human resources (HR), operations research, and strategy. In all regression models, management is taken as a base and other disciplines are compared to it.

In testing Hypotheses 3-8, we also control for social capital. Social capital was found to be an important predictor of research productivity (e.g., Bäker, 2015;
Hong \& Zhao, 2016), as the number of coauthored papers in the field of management has grown recently (Acedo, Barroso, Casanueva, \& Galán, 2006). This social capital variable was measured as the number of unique coauthors an academic collaborated with throughout their career.

Fernández-Zubieta et al. (2015) found that productivity post-mobility depends on the direction of mobility, namely, whether an academic moved up or down the research visibility continuum. Specifically, they found that mobility to more prestigious institutions leads to higher research productivity, although mobility to less prestigious institutions leads to a decrease in productivity. To incorporate this finding in our study, we control for the general direction of mobility in an academic career by including the direction of mobility control variable. This variable captures the difference between the weighted research visibility of post-PhD workplaces and the research visibility of doctoral origin. The research visibility of post-PhD workplaces was measured using the weighted volume metric from the Global Research Performance Database and additionally weighted by the proportion of time spent by an academic working for each institution in their career.

\section{Data Analysis}

To test Hypotheses 1 and 2, which predict the presence of mobility in academic careers, we used multinomial logistic regression, which is appropriate when the outcome variable is categorical. The rest of our dependent variables displayed a non-normal distribution, as confirmed by the Shapiro-Wilk test $(p<0.001)$ and Levene's variance homogeneity test. We followed previous researchers who found themselves in a similar situation (e.g., Cruz-Castro \& Sanz-Menendez, 2010) and used negative binomial regression, which is a recommended analytical technique for over-dispersed count data (Long, 1997). The mean dispersion version of negative binomial regression was chosen because it delivered larger (least negative) log likelihood. The effect sizes from negative binomial regression were calculated using the procedure described in Seibert et al. (2017). Where a variable was measured in meaningful units, we reported an unstandardized effect size. In all other cases, we presented a standardized effect size. We used the Baron and Kenny procedure to test for mediation (Baron \& Kenny, 1986) in H3. The significance of indirect effects was tested through the Sobel test. All analysis was performed in Stata 13. 


\section{RESULTS}

In our sample of 376 academics, 185 individuals $(49 \%)$ never moved from the country where they received their $\mathrm{PhD}$. Out of 191 internationally mobile academics, 92 individuals $(25 \%$ of the overall sample) moved once, 68 individuals $(18 \%$ of the overall sample) moved twice, and the rest moved three times or more, with the maximum number of international moves equal to six times. Of the 185 individuals who stayed in the same country throughout their careers, 58 (31\%) never moved from their PhD school.

See Table 2 for the descriptive statistics for all variables.

As seen from the results reported in Table 3, H1, which suggested that early-career capital is positively related to mobility, received partial support. Research visibility of early-career publications is positively related to international mobility, with one standard deviation change in visibility increasing the probability of an internationally mobile career by $34 \%$. Research visibility of post-PhD workplaces is, however, negatively related to domestic mobility. Academics who worked in more prominent institutions after their $\mathrm{PhD}$ were less likely to move within the same country: One standard deviation change in research visibility decreased the probability of moving within the country by $51 \%$ (see Table 3). Among the control variables, age is positively related to mobility and different discipline areas had significantly different mobility rates (see Table 4 for mobility breakdown by discipline). H2 also received partial support. Male academics in our sample are 2.4 times more likely to be internationally mobile than female academics. The probability of domestic mobility does not differ significantly across genders.

H3 suggested that mobility (domestic and international) mediates the relationship between earlycareer capital and research-career capital. The analysis revealed that this hypothesis is not supported. Although early-career capital and mobility are separately and significantly related to researchcareer capital, the potential mediation effect is not significant, as per the two-tailed Sobel test. One additional paper published in the first 3 years post$\mathrm{PhD}$ is associated with a 5\% increase in career-long volume of research. Domestic and international mobility (binary, throughout the entire career) are associated with a $20 \%$ and $28 \%$ increase in careerlong volume of research, respectively. One standard deviation increase in research visibility of doctoral origin is associated with a $42 \%$ increase in careerlong impact of research. One standard deviation increase in research visibility of early-career publications is associated with a $38 \%$ increase in career-long impact of research. Both domestic and international mobility (binary, throughout the entire career) show signs of being positively related to the impact of research, although the significance of this relationship depends on the specification of the model (see Model 4 in Table 5, Model 6 in Table 6, and Model 2 in Table 8).

Hypotheses 4 and 5 are not supported. As seen from Models 1 and 4 in Table 6, the relationship between international mobility to first employer is significantly and negatively related to both volume and impact of research, contrary to our assumptions. International mobility to the first employer is associated with a $12 \%$ decrease in volume and a $23 \%$ decrease in impact of research. Again, contrary to our assumptions, international mobility between the 2nd and the 7th year post-PhD is significantly related to a $13 \%$ increase in the volume of research (see Models 2 and 5 in Table 6).

H6 received partial support. As seen in Models 3 and 6 in Table 6 , radical step mobility is positively related to the volume of research, but we did not find evidence of significant association with the impact of research. To investigate this in detail, we separately analyzed the effect of upward and downward radical step mobility on research-career capital. This supplemental analysis, reported in Table 7, revealed that only upward mobility has a significant and positive effect on the volume and impact of research. Academics who made at least one upward radical step in mobility have a $17 \%$ higher volume and a $25 \%$ higher impact of research.

H7, which tested the influence of multiple moves on research-career capital, received partial support. In comparison with those who moved only once throughout their academic career, academics who moved twice had a $23 \%$ higher volume of research, academics who moved three times had a $20 \%$ higher volume of research, and academics who moved four times had a $24 \%$ higher volume of research. For the limited number of academics who moved five and six times, the associated increase in volume of research was $28 \%$ and $56 \%$, respectively. Additional moves do not contribute to a significant increase in the impact of research, with the exception of those who moved six times (however, this finding should be treated with caution as only a few academics in our sample had this level of mobility). The results of this analysis are reported in Table 8. Figures 2 and 3 


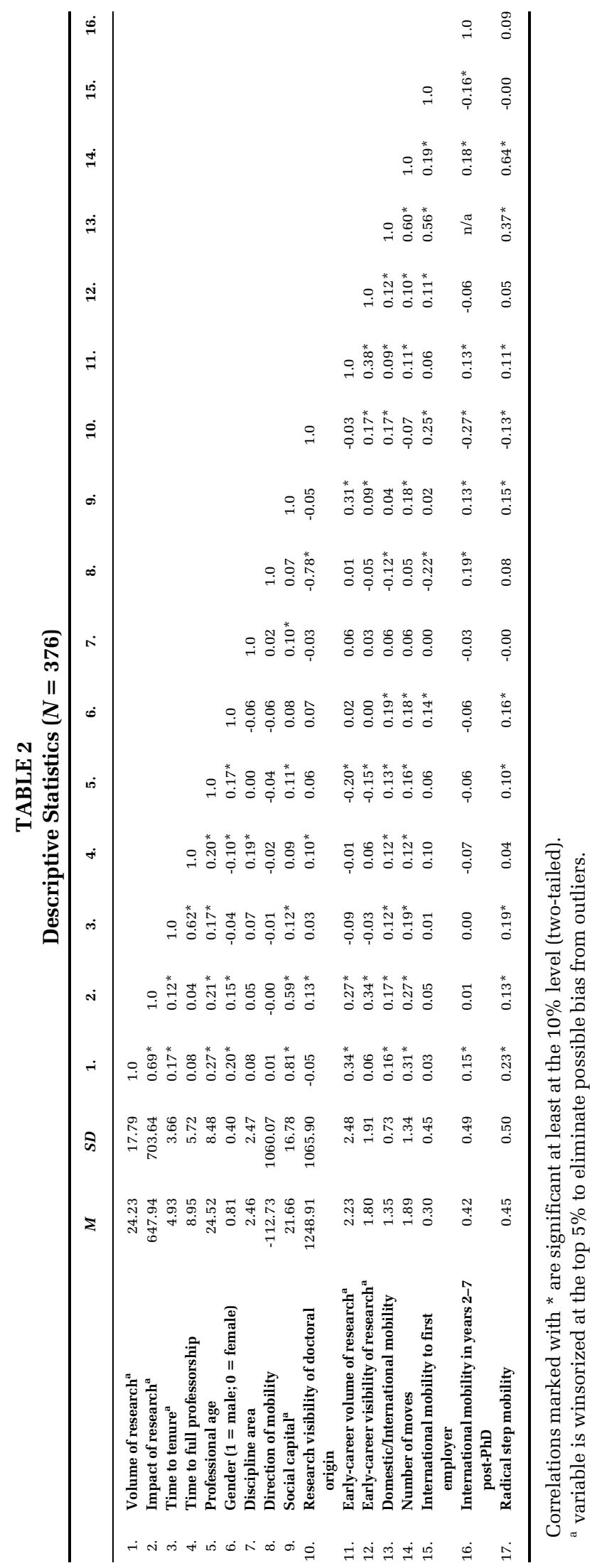


TABLE 3

Results of Multinomial Logistic Regression Analysis for Mobility

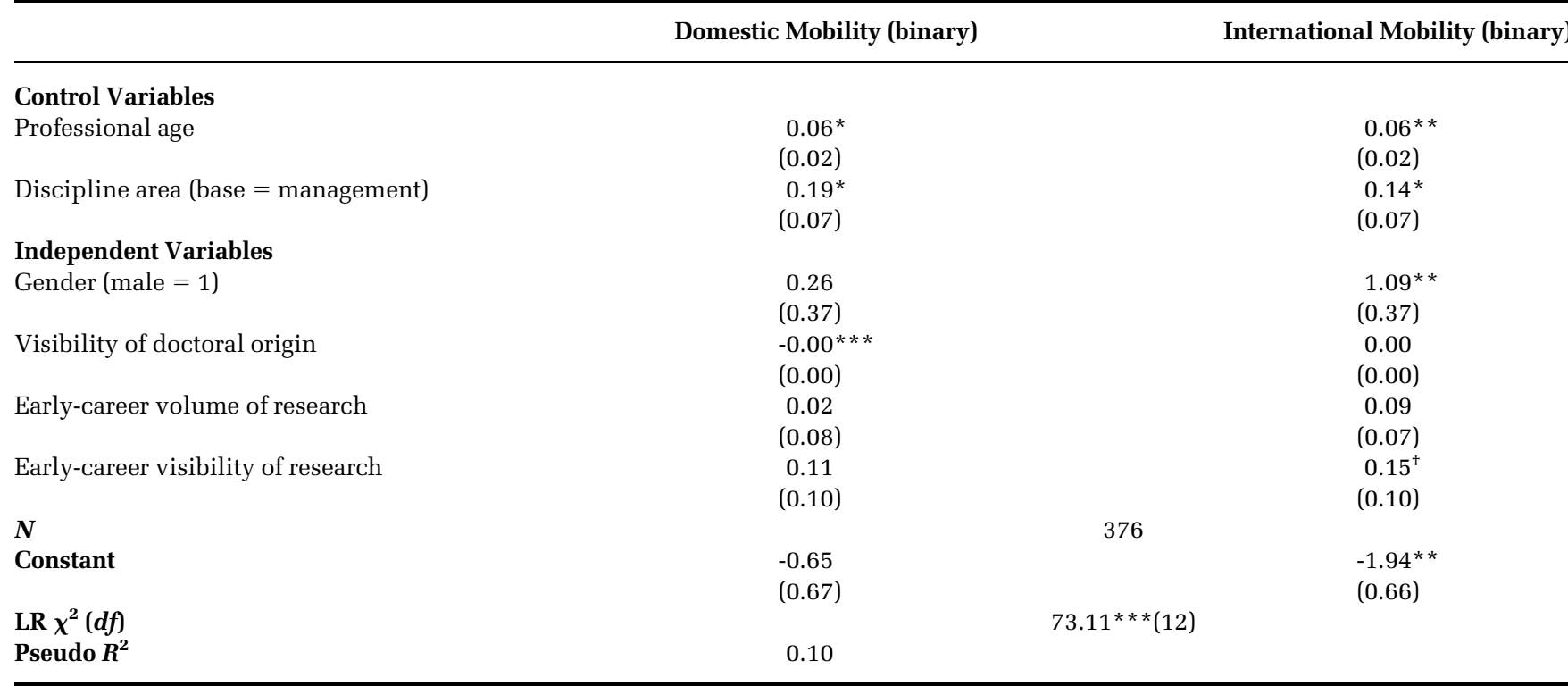

${ }^{\dagger} p<0.10 ;{ }^{*} p<0.05 ;{ }^{* *} p<0.01 ;{ }^{* *} p<0.001$. Significance levels are one-tailed for hypothesized relationships and two-tailed otherwise.

summarize our findings for two metrics of researchcareer capital.

H8a, which suggested a longer time to tenured rank for academics with mobile careers, is supported (see Model 1 in Table 9). Specifically, academics who moved two to four times in their careers were promoted more slowly than their less mobile peers. Academics who moved four times in their careers also took longer to be promoted to full professorship, which lends partial support to H8b. It is worth noting that male academics received promotion to tenured and full professorship significantly faster than female academics, with their time to promotion being shorter by $19 \%$ and $20 \%$, respectively. A separate analysis also showed that time to promotion to a tenured rank was $27 \%$ longer for internationally mobile academics relative to their non-mobile and domestically mobile peers. The time to promotion to full professorship was $25 \%$ longer for internationally mobile academics relative to their domestically mobile peers, but did not differ significantly from their non-mobile peers.

\section{DISCUSSION}

\section{Early-Career Capital and Mobility}

Our exploration of mobility choices and consequences started with testing how access to mobility is influenced by early-career capital and the individual

TABLE 4

Distribution of Mobility by Discipline

\begin{tabular}{|c|c|c|c|c|c|}
\hline Discipline & $\begin{array}{l}\text { No. } \\
\text { Academics } \\
\text { in Sample }\end{array}$ & $\begin{array}{l}\text { Average No. } \\
\text { Domestic } \\
\text { Moves }\end{array}$ & $\begin{array}{c}\text { Average No. } \\
\text { International } \\
\text { Moves }\end{array}$ & $\begin{array}{l}\text { \% Academics With Upward } \\
\text { Radical Step Mobility } \\
\text { (at least once in their career) }\end{array}$ & $\begin{array}{c}\text { \% Academics With } \\
\text { Downward Radical Step Mobility } \\
\text { (at least once in their career) }\end{array}$ \\
\hline Management & 145 & 0.9 & 0.9 & $47 \%$ & $44 \%$ \\
\hline Accounting & 21 & 1.2 & 0.9 & $48 \%$ & $57 \%$ \\
\hline Economics & 52 & 1.1 & 1.1 & $63 \%$ & $56 \%$ \\
\hline Finance & 46 & 1.1 & 1.1 & $59 \%$ & $52 \%$ \\
\hline MIS & 27 & 1.0 & 1.0 & $56 \%$ & $41 \%$ \\
\hline Marketing & 38 & 1.1 & 0.5 & $34 \%$ & $26 \%$ \\
\hline Operations research & 11 & 0.7 & 0.7 & $27 \%$ & $55 \%$ \\
\hline OB/HR & 27 & 1.2 & 0.7 & $56 \%$ & $59 \%$ \\
\hline Strategy & 9 & 1.3 & 1.4 & $67 \%$ & $56 \%$ \\
\hline
\end{tabular}


TABLE 5

Results of Mediation Analysis for Domestic/International Mobility (binary)

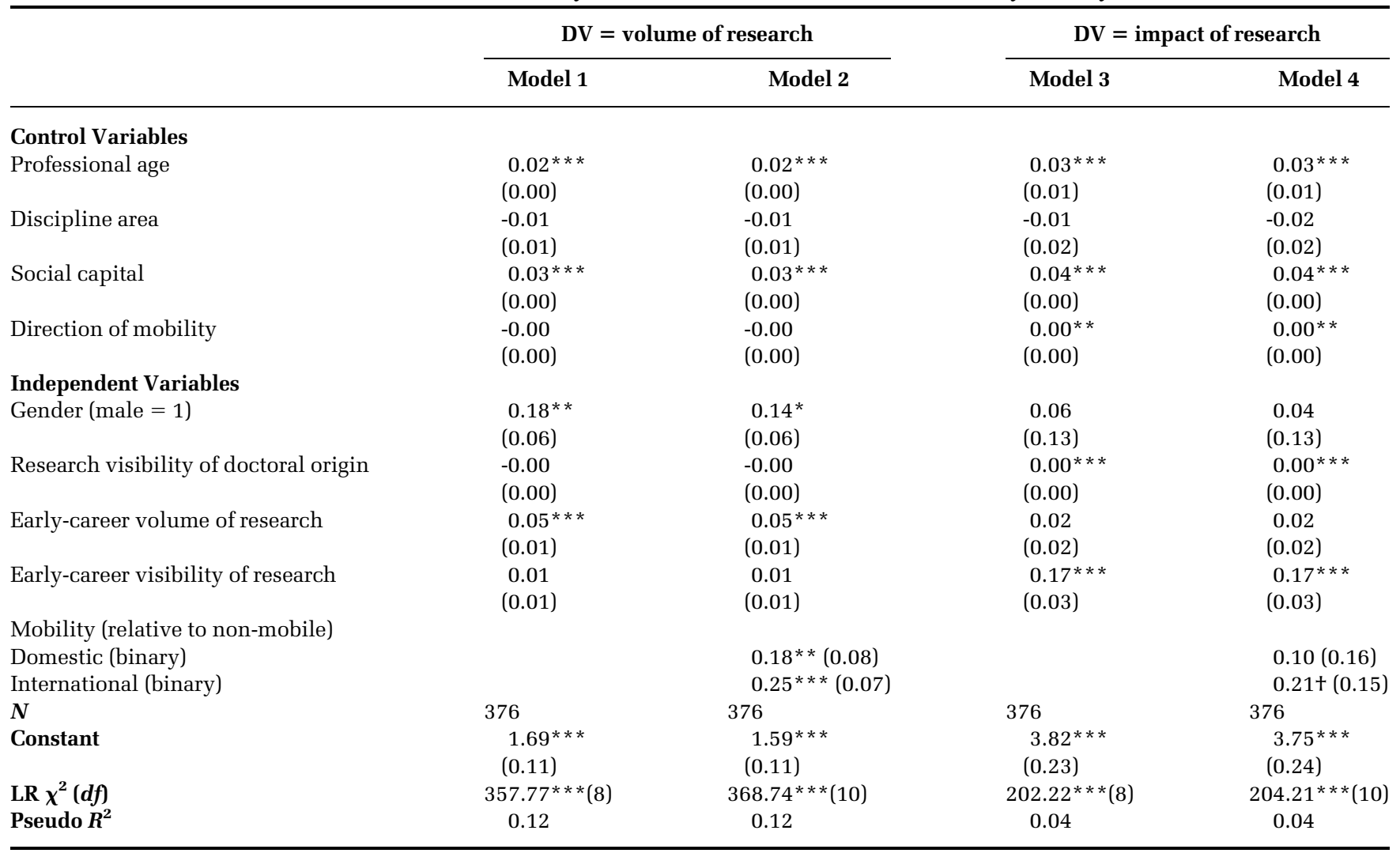

${ }^{\dagger} p<0.10 ;{ }^{*} p<0.05 ;{ }^{* *} p<0.01 ;{ }^{* *} p<0.001$. Significance levels are one-tailed for hypothesized relationships and two-tailed otherwise.

demographic traits of European business school academics. Our findings indicate that domestic mobility seems to be driven by push rather than pull factors. Academics who started their professional journey in highly research-visible $\mathrm{PhD}$ schools and were able to stay there after graduation tended to be less likely to move domestically. At its extreme, this categorizes those individuals as "inbred faculty" (Horta, 2013) and, in our sample, $15 \%$ of academics fall into this category. A study by Horta and colleagues (2010) warns that this extreme lack of mobility leads to a decrease in research productivity and international collaboration.

Two potential forces might impede mobility from highly productive $\mathrm{PhD}$ schools. First, these institutions might be interested in retaining their best graduates because they have successfully demonstrated their research capabilities. In addition, these graduates possess some institution-specific knowledge that might facilitate their transition into service and teaching faculty roles where they could add value more easily. Second, graduates might be unwilling to move from their alma mater if there is a lack of workplaces with comparably high research productivity. In our sample, the highest number of non-mobile academics are employed by Bocconi University in Italy. In the industry landscape of Italian business education, Bocconi University significantly exceeds all other institutions both in terms of the volume and visibility of its research output. For example, its closest competitor, University of Bologna, published 162 papers and 467 units of visibility-adjusted volume in the period 2007-2015, compared to Bocconi's 526 papers and 1711 units of visibility-adjusted volume in the same period (Ryazanova et al., 2017).

Notably, the research visibility of doctoral origin does not have the same effect on international mobility. Among all the components of early-career capital tested in H1, only the visibility of early-career publications was found to have a positive association with international mobility. This finding differs from the established view that it is primarily volume that drives mobility (Allison \& Long, 1987; Edler, Fier, \& Grimpe, 2011). Our data point to the possibility that those who have international mobility aspirations 
TABLE 6

Results of Regression Analysis for Mobility Patterns

\begin{tabular}{|c|c|c|c|c|c|c|}
\hline & \multicolumn{3}{|c|}{ DV = volume of research } & \multicolumn{3}{|c|}{ DV = impact of research } \\
\hline Gender $($ male = 1) & $\begin{array}{l}0.19^{* *} \\
(0.06)\end{array}$ & $\begin{array}{r}0.19^{\dagger} \\
(0.11)\end{array}$ & $\begin{array}{l}0.13^{*} \\
(0.06)\end{array}$ & $\begin{array}{c}0.10 \\
(0.13)\end{array}$ & $\begin{array}{c}0.19 \\
(0.22)\end{array}$ & $\begin{array}{c}0.03 \\
(0.13)\end{array}$ \\
\hline Early-career volume of research & $\begin{array}{l}0.05^{* * *} \\
(0.01)\end{array}$ & $\begin{array}{l}0.05^{* * *} \\
(0.01)\end{array}$ & $\begin{array}{l}0.05^{* * *} \\
(0.01)\end{array}$ & $\begin{array}{c}0.03 \\
(0.02)\end{array}$ & $\begin{array}{c}0.03 \\
(0.03)\end{array}$ & $\begin{array}{c}0.02 \\
(0.02)\end{array}$ \\
\hline Early-career visibility of research & $\begin{array}{c}0.01 \\
(0.01)\end{array}$ & $\begin{array}{c}0.01 \\
(0.02)\end{array}$ & $\begin{array}{c}0.00 \\
(0.01)\end{array}$ & $\begin{array}{l}0.17^{* * *} \\
(0.03)\end{array}$ & $\begin{array}{l}0.15^{* * *} \\
(0.04)\end{array}$ & $\begin{array}{l}0.17^{* * *} \\
(0.03)\end{array}$ \\
\hline \multicolumn{7}{|l|}{ Mobility (relative to non-mobile) } \\
\hline $\begin{array}{l}\text { Domestic (binary) } \\
\text { International (binary) }\end{array}$ & & & $\begin{array}{l}0.14 *(0.08) \\
0.19 * *(0.08)\end{array}$ & & & $\begin{array}{l}0.09(0.16) \\
0.19(0.17)\end{array}$ \\
\hline Radical step mobility (binary) & & & $\begin{array}{l}0.10^{*} \\
(0.05)\end{array}$ & & & $\begin{array}{c}0.03 \\
(0.12)\end{array}$ \\
\hline $\boldsymbol{N}$ & 376 & 184 & 376 & 376 & 184 & 376 \\
\hline Constant & $\begin{array}{l}1.68^{* * *} \\
(0.11)\end{array}$ & $\begin{array}{l}1.62^{* * *} \\
(0.18)\end{array}$ & $\begin{array}{l}1.59^{* * *} \\
(0.11)\end{array}$ & $\begin{array}{l}3.79^{* * *} \\
(0.22)\end{array}$ & $\begin{array}{l}3.82^{* * *} \\
(0.38)\end{array}$ & $\begin{array}{l}3.76^{* * *} \\
(0.24)\end{array}$ \\
\hline $\operatorname{LR} \chi^{2}(d f)$ & $363.01^{* * *}(9)$ & $168.67^{* * *}(9)$ & $372.17^{* * *}(11)$ & $206.92^{* * *}(9)$ & $94.76^{* * *}(9)$ & $204.26^{* * *}(11)$ \\
\hline Pseudo $R^{2}$ & 0.12 & 0.11 & 0.12 & 0.04 & 0.03 & 0.04 \\
\hline
\end{tabular}

${ }^{\dagger} p<0.10 ;{ }^{*} p<0.05 ;{ }^{* *} p<0.01 ;{ }^{* *} p<0.001$. Significance levels are one-tailed for hypothesized relationships and two-tailed otherwise.

target more visible journals at the very start of their publishing career to make sure that their publications can serve as accepted career currency in the global labor market.

Not everyone, however, can afford to move internationally. This particularly applies to female academics, as we found in the testing of H2. Although early-career productivity does not differ significantly across genders, women are significantly less likely to be internationally mobile. The literature indicates that this lack of mobility is rooted in personal life rather than the female academics' lack of awareness about the professional benefits of mobility (Oliver, 2012; Sang et al., 2013; White et al., 2011). Female academics are often expected to "have it all," namely, to be a caring mother/daughter, a supportive partner or spouse, and to perform in the workplace on a par with their male peers, who are more likely to have lighter caring responsibilities. The adjustment cost of international mobility might seem to many female academics to be the proverbial straw that breaks the camel's back. Although the literature indicated that, in general, prior experience of international mobility is conducive to further international mobility (Børing et al., 2015; Equeter \& Hellemans, 2016), internationally mobile female academics interviewed by Sang et al. (2013) unanimously expressed their unwillingness to move again due to the costs of unsettling their families.

\section{Mobility Choices and Consequences for Research- Career Capital}

The second part of our analysis explored the impact of specific mobility choices on research-career capital, with a separate focus on volume and impact of research. Does international mobility work better as an early-career or mid-career strategy? Does mobility between institutions with radically different research visibility have a significantly different effect on performance relative to a more incremental mobility strategy? Do additional moves bring additional performance increases? 
TABLE 7

Results of Supplemental Regression Analysis for the Direction of Radical Step Mobility

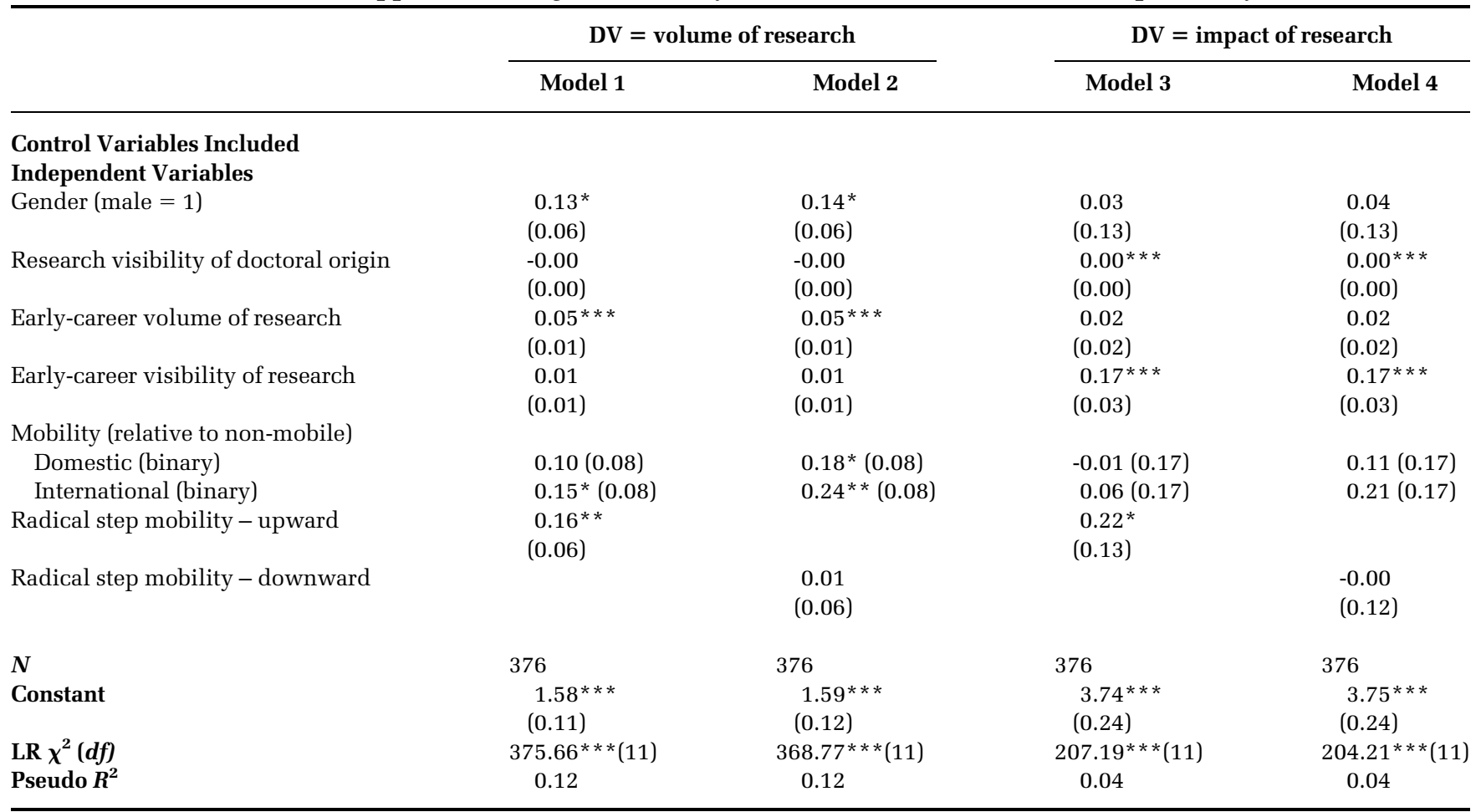

${ }^{*} p<0.05 ;{ }^{* *} p<0.01 ;{ }^{* *} p<0.001$. Significance levels are one-tailed for hypothesized relationships and two-tailed otherwise.

To address the first question, our study adds greater insight into the performance consequences of different types of mobility. Although research on postdoctoral mobility indicates that very early career mobility is beneficial for research productivity (Cruz-Castro \& Sanz-Menendez, 2010), our study shows that this only applies to domestic mobility. Although both domestic and international mobility are positively related to research-career capital overall, international mobility to the very first employer is negatively associated with both volume and impact of research. Evidently the costs of international mobility (Oliver, 2012; Richardson \& Zikic, 2007) increase when the graduates are still in the process of publishing their first papers and creating an initial teaching portfolio.

However, in the context of a focused strategy to improve research-career capital, international mobility seems to be most effective as an early-career rather than a late-career strategy. Moving between the $2 \mathrm{nd}$ and the 7 th year post-PhD is associated with a higher volume of research. On average, the academics in our sample graduated from their $\mathrm{PhD} 25$ years ago. Of the internationally mobile academics in the sample, $80 \%$ experienced mobility before their 8th year post-PhD, rather than later in their careers. This supports the assumption that international mobility drives research-career capital, rather than vice versa. In our sample the accumulation of research-career capital, which happens later in an academic career, did not lead to higher international mobility.

Although the literature suggested that international mobility is a desirable strategy for academics who have not yet formed strong career ties to any institution (Cruz-Castro \& Sanz-Menendez, 2010; Zubieta, 2009), which led to Hypotheses 4 and 5 , our data offer a more nuanced view of early-career mobility. Our findings suggest that it is important for a $\mathrm{PhD}$ graduate to settle into the profession for a short while, building a research and teaching portfolio, before making international moves. It is, however, important to move reasonably early, because later in academic careers personal constraints may become more pronounced, with families growing and children reaching high school age (Azoulay et al., 2017). These results do not contradict prior literature: If the only international move one makes is immediately after $\mathrm{PhD}$, this is still more beneficial than not moving at all. However, stronger benefits could be 
TABLE 8

Results of Regression Analysis for Mobility Patterns (Number of Moves)

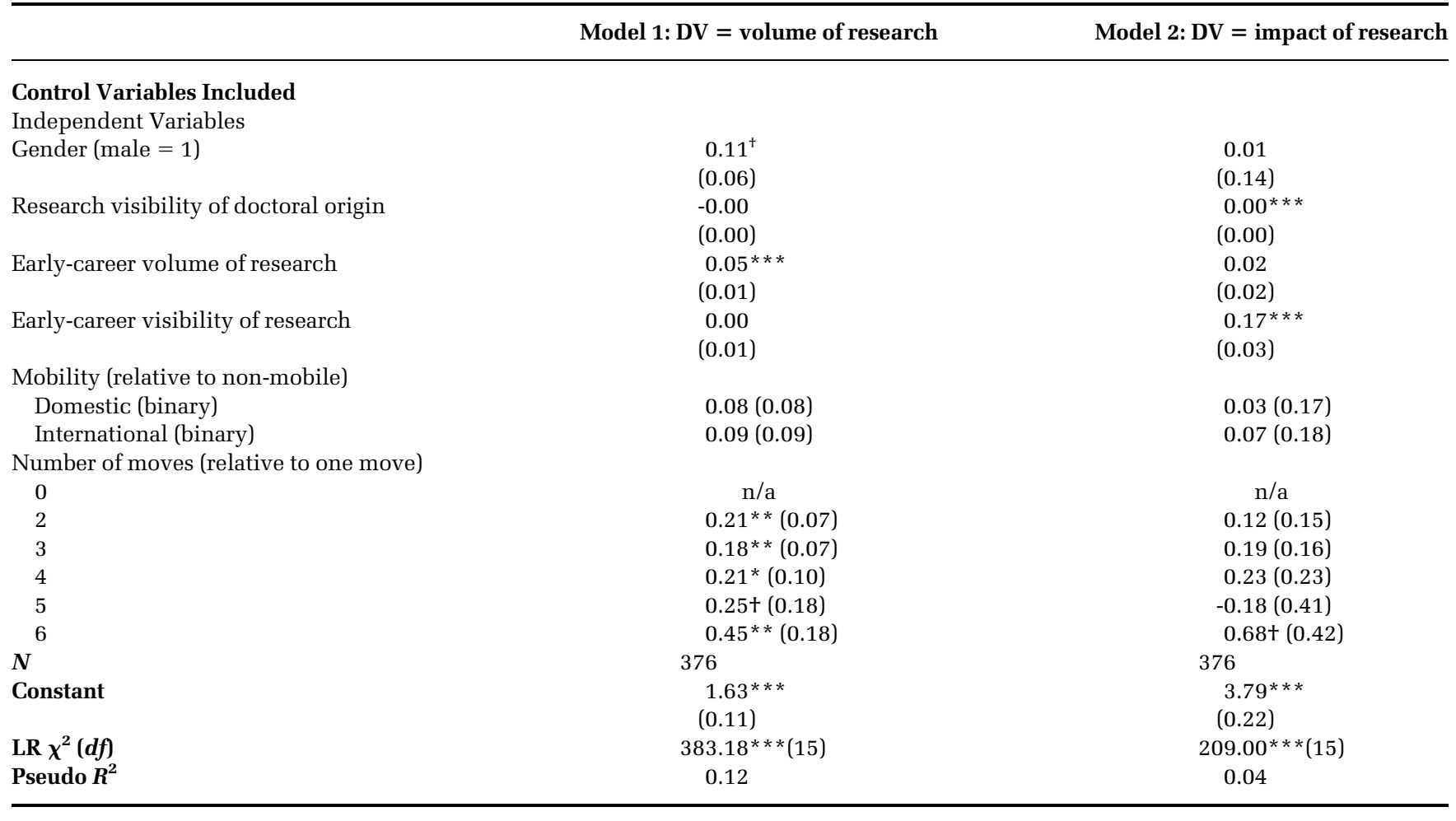

${ }^{\dagger} p<0.10 ;{ }^{*} p<0.05 ;{ }^{* *} p<0.01 ;{ }^{* * *} p<0.001$. Significance levels are one-tailed for hypothesized relationships and two-tailed otherwise.

extracted from international mobility if timing is taken into account.

The need for careful choices around "the window of mobility" is an important insight for junior faculty and those who mentor them. It also has implications for science policies that support the mobility of researchers, such as the Marie Curie Program in the EU or the Fulbright Program in the US. If international mobility is promoted with a view to achieving an increase in research outputs, funders need to be mindful of the desired career stage of applicants. If international mobility is promoted for other policy reasons, then other considerations ought to be taken into account.

In relation to the second question, our testing of H6 found that moving in "large leaps" between institutions with dramatically different research visibility may be a productive strategy. This is the case where an individual moves from a less researchvisible to a more research-visible workplace. However, for those who hope to achieve higher research productivity by being a "big fish in a little pond" the effort of negotiating idiosyncratic deals with a new employer (Aguinis \& O'Boyle, 2014)—resulting in "star" employees getting a disproportionately high share of resources-may be greater than expected. This unequal allocation of funding may go against the shared sense of procedural justice and undermine collegiality within an institution, isolating research stars and their research groups in turn. This isolation may undermine their ability to leverage institutional networks in navigating the complexities of teaching and service work or in subsequent bids for funding. Combined, this may result in increased effort to achieve the same outcome. In addition, in institutions that have a significantly less developed culture of supporting research, the lack of administrative infrastructure may become a hidden barrier for delivering research outcomes. Again, the lack of social connections with colleagues may impede access to administrative support.

In answering the third question, we found that the strategy of multiple moves delivers positive performance outcomes, but mostly in terms of volume, which partially supports H7. This finding was unexpected and counterintuitive. Most studies of research productivity, including ours, observe high correlation between the number of papers published and the number of citations accumulated by these papers (e.g., $r=0.69$, as seen in Table 2). Yet, in our 
FIGURE 2

Factors Associated With Volume of Research. IM = international move

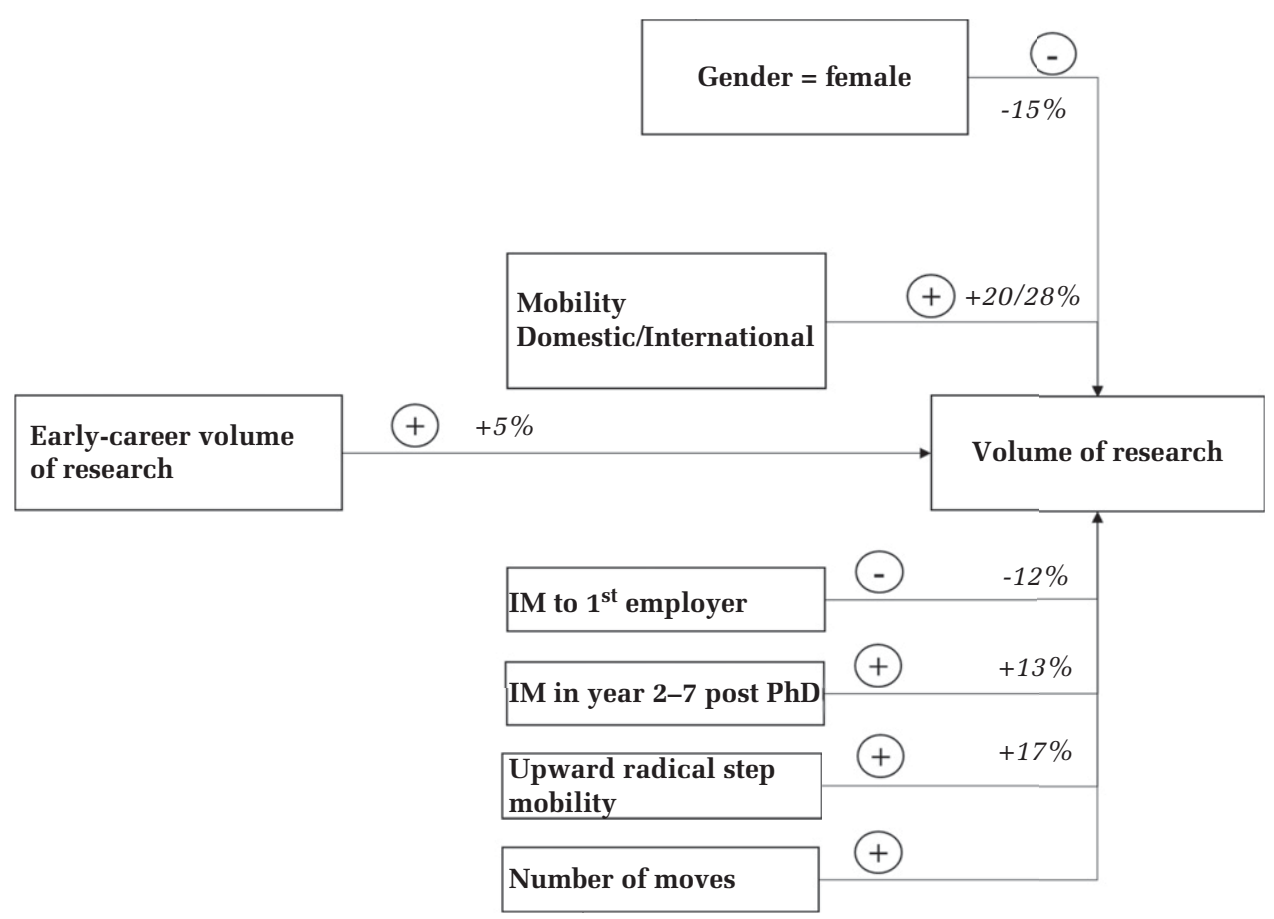

regression results, a mobility strategy that drives the volume of research has barely any impact on the number of citations. This finding questions the established narrative that one of the key reasons for mobility is knowledge sharing within the scientific community (Morano-Foadi, 2005), or, at least, that this knowledge sharing leads to an automatic increase in the scholarly impact at the individual level.

FIGURE 3

Factors Associated With Impact of Research. IM = international move

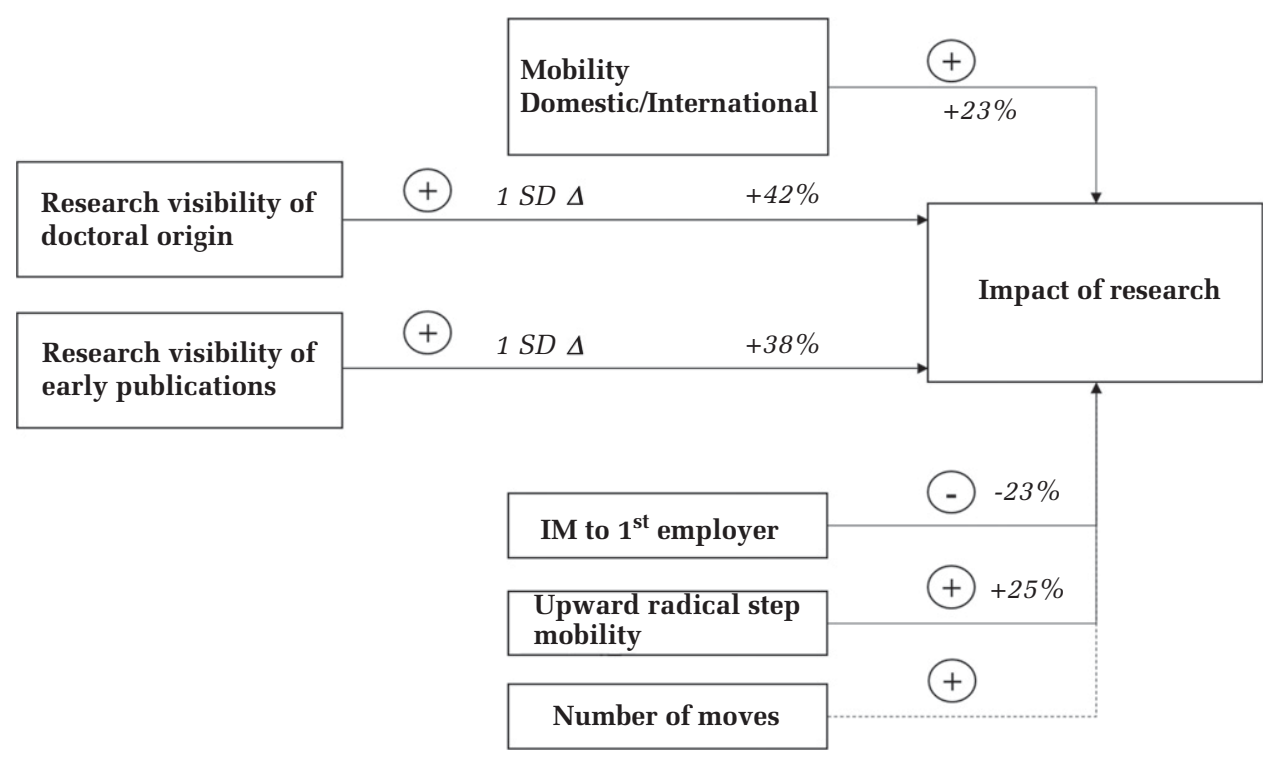


TABLE 9

Results of Negative Binomial Regression Analysis for Academic Promotion Outcomes

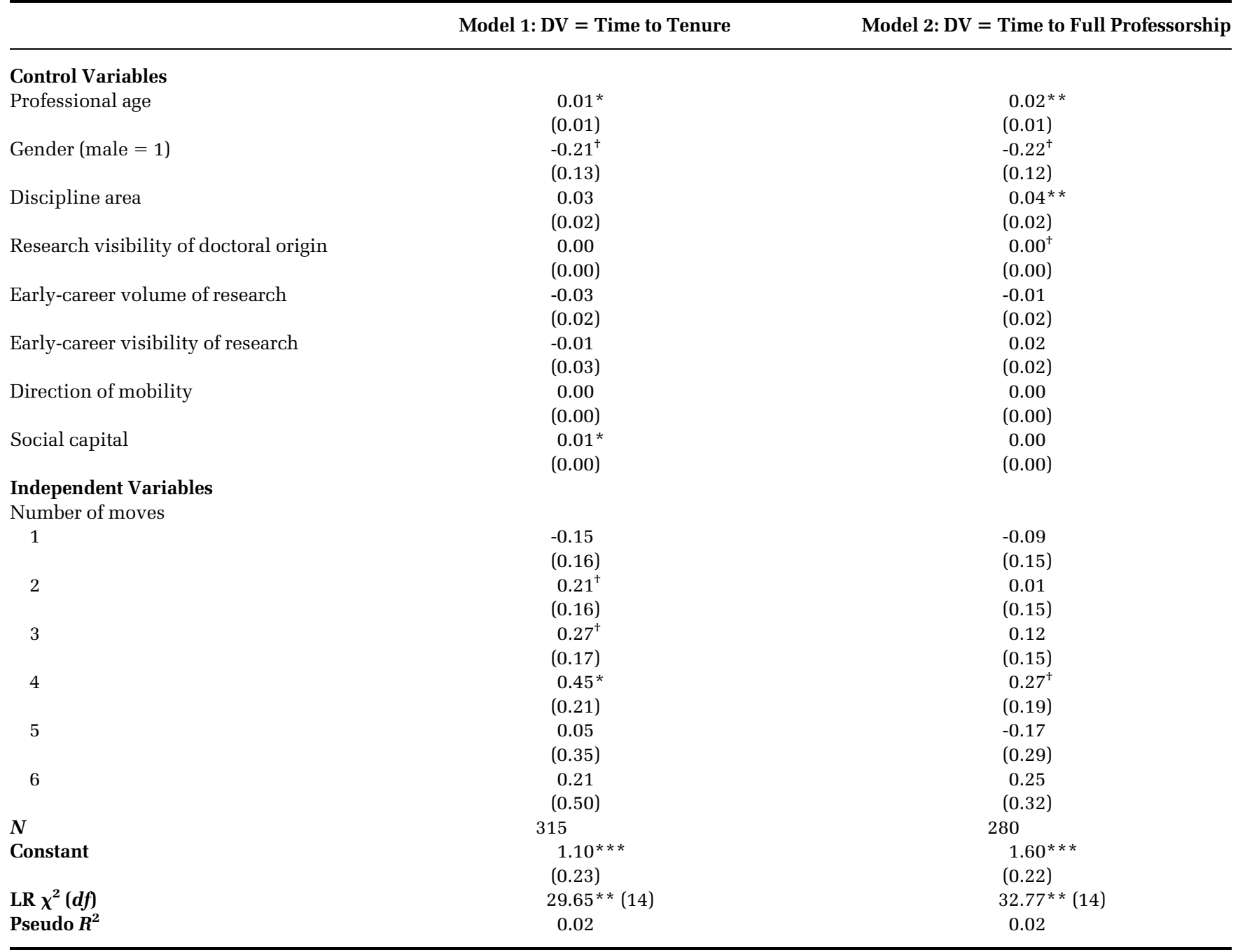

${ }^{\dagger} p<0.10 ;{ }^{*} p<0.05 ;{ }^{* *} p<0.01 ;{ }^{* *} p<0.001$. Significance levels are one-tailed for hypothesized relationships and two-tailed otherwise.

Why would this be so? We suggest that two interconnected mechanisms may contribute to this outcome. First, to move multiple times, an academic should produce a constant stream of new publications, in some cases sacrificing journal visibility for lower risks of rejection, and hence, on average, increased outcomes per input of effort. Lower journal visibility results in a smaller audience of readers who could potentially cite one's research.

Second, among other factors, citation counts are driven by the number of references used in a paper (Mingers \& Xu, 2010). This indicates that citation behavior is partly driven by reciprocity in academic networks. To trigger this reciprocal behavior, academics need to have a deep knowledge of their colleagues' research, so that they can cite it appropriately. The acquisition of such deep knowledge takes time and requires face-to-face interaction, often in informal contexts (Storme, Faulconbridge, Beaverstock, Derudder, \& Witlox, 2017). Academics who move a lot in their careers may not have enough time to embed themselves in their workplace communities.

\section{Mobility and Academic Promotion}

The final section of our analysis examined the consequences of mobility choices on the speed of promotion to tenured and full professorship. Prior research in life sciences explored the link between postdoctoral mobility and promotion (Cruz-Castro \& Sanz-Menendez, 2010). Our study extended this 
research to the careers of full-time business school faculty and demonstrated that the choice between early promotion and research success is present in this context. Another novel aspect of our study was to look at promotion to full professorship. We also complemented the research that looked at the link between industry trends in academic publishing and the probability of achieving the number of publications required for promotion (Certo et al., 2010). Our study looks at another industry trend, namely, increased inter-organizational and international mobility, and links it to academic promotion outcomes.

H8a was supported. For faculty who have an ambition to be promoted to a tenured rank early in their career, a strategy of remaining within the same country or even in the same institution seems to be preferable. This is because mobility in general and international mobility in particular delays promotion. The effect of mobility on the speed of promotion to full professorship is less pronounced: Only those who moved four times had to wait longer to be promoted, which partly supports H8b.

Why then might academics decide to leave secure paths to promotion and go abroad? First, there may be personal reasons for international mobility. Academics may be willing to bear the cost of a longer time to promotion to achieve a higher quality of life in another country for themselves and their families (Lepori et al., 2015). Second, academics may value research-career capital more highly than promotion, because growing this capital helps them maintain their academic identity as successful researchers (Day, 2011). Third, mobility may give academics the freedom to build their careers following Dowd and Kaplan's (2005) "boundaryless pattern," rather than being dependent on any one academic employer.

The consequences of the delay in academic promotion are multifaceted. For an individual, a delay in getting a promotion may be a matter of personal and financial anxiety (Richardson, 2009). For an organization, a delay in promotion might be a useful outcome, because academics seeking promotion are motivated to be productive. Once promotion is achieved, motivation to publish diminishes (Miller et al., 2011). In the field of business and management research, however, the consequences of a longer time to promotion may be detrimental. Increased autonomy and job security brought on by promotion often motivate academics to engage in more original (and risky) research, opening novel streams of scientific inquiry (Miller et al., 2011). Therefore, by delaying promotion, international mobility may also motivate academics to choose safer, more mainstream research for longer in their careers. The unwillingness of scholars to try bold ideas slows down the development of science. We suggest that investigating whether increased mobility leads to more conservative publishing choices might be an interesting opportunity for future research.

To alleviate this potential negative side effect, it is important to understand the reasons behind longer time to promotion for mobile academics. The existing literature has generated a number of insights, pointing toward lack of recognition due to "cultural distance" between countries (Richardson \& Zikic, 2007), differences in career rules and expectations in different national contexts (Richardson, 2009), and social construction of the labor market (Cruz-Castro \& Sanz-Menendez, 2010). It is also possible that mobile academics are over-represented among the administrators of internationally oriented research centers, which would impose heavy administrative loads upon them, and thus, might slow down their promotion. Testing these alternative explanations to better understand which of them should be addressed to influence promotion patterns would be a productive avenue for future research on mobile academic careers in general and internationally mobile careers in particular.

We also found that it takes female academics longer to be promoted to tenured and full professorship. International mobility may help build characteristics desirable for promotion (or senior academic leadership roles), such as research productivity and international connections (Horta, 2013; Zubieta, 2009). Therefore, a population with poorer access to mobility is disadvantaged in academic promotion. White et al.'s (2011) study revealed that in their sample of Australian universities, university leaders were expected to match the profile of a "stellar scientist." Their research found that women, who carried heavier teaching loads at junior levels and were expected to provide more pastoral care at senior levels, found it difficult to achieve this research profile. This undermined women's ability to influence decisions at a senior level. Our study of international mobility offers another reason why women might struggle to achieve senior positions, where they could contribute to more gender-balanced governance in universities.

Interestingly, Welch (1997) found that female academics hired externally were more successful in securing senior positions than their female peers who had not moved between institutions. This might be due to the fact that in applying for senior-level jobs elsewhere, it is easier for female academics to 
construct the career narrative that highlights their achievements. In internal promotion, it becomes hard to downplay the struggles of managing worklife balance, or the possible teaching and service trade-offs needed to achieve the required research productivity. These struggles and trade-offs were clearly visible to current colleagues, creating an image of a professional who does not fit the profile of a future academic leader. Academic leaders, irrespective of the pressures they face, are expected to have a strong reputation for collegiality, patience, and good listening skills that would enable them to be successful in enacting the bottom-up governance approach typical for academia (Wang \& Frederick, 2018). It is important, therefore, for all business schools to implement practices that support research productivity in general and international mobility in particular as another mechanism of career development for female faculty. These practices should be tailored to the specific needs of female and other employees who are primary caregivers for children and elderly relatives. Such diversity practices support workplace well-being and engagement for all groups of employees (Downey, Van der Werff, Thomas, \& Plaut, 2015).

\section{Implications for Doctoral Education in Business Schools}

Our study of international mobility has several implications for the way we prepare doctoral students for future careers as business school faculty. First, academics supervising doctoral students in business schools should be aware of the increased importance of early publications for their students. Both the volume and the visibility of publications matter. Early publishing is beneficial for career-long volume of research. Publishing in visible outlets is beneficial for career-long scholarly impact and is particularly important for graduates seeking academic jobs outside the country of their PhD. Given the European tradition of writing doctoral theses in the form of a manuscript (e.g., Phillips \& Pugh, 2005), this would require an additional effort in helping students prepare high-quality journal submissions as early in a $\mathrm{PhD}$ program as possible. $\mathrm{PhD}$ directors ought to consider whether academics who take on the supervision of doctoral students have at least some expertise in targeting highly visible journals. It might be equally important that the supervisors themselves are visible at conferences and active on editorial review boards so that they can transfer the knowledge to their doctoral students. Early socialization of $\mathrm{PhD}$ students into the professional community by motivating them to submit, present, and review papers at major international conferences is another step toward building early-career portfolios.

Second, in an increasingly international scientific community, major conferences become useful outlets for socializing doctoral students into mobile academic careers. Conferences such as the Academy of Management and the European Academy of Management, among others, offer student mentoring workshops and doctoral consortia. These workshops enable doctoral students to meet with their international peers and get first-hand advice about academic careers worldwide. This might inform specific mobility decisions and reduce adjustment costs if, in the future, a student decides to move internationally.

Third, although international mobility has its benefits, it should not be promoted as a "one-size-fits-all" solution. All effect sizes observed in our study of international mobility range from small to moderate. Therefore, the ability to move internationally plays an important but not determining role in an academic's ability to achieve high research productivity. For those doctoral students who cannot or do not want to move internationally, there are other viable ways to grow research productivity. Business schools must take responsibility for preparing doctoral students for future careers, whether mobile or immobile. After all, despite different career patterns, all academics in our sample are employed by highly research-visible schools, which shows that there are multiple routes to career success, if we define career success as being a tenured faculty member in a research-visible business school.

\section{IMPLICATIONS FOR PUBLIC POLICY}

Inequalities in research production that stimulate academic inbreeding, as discussed earlier, may result from a government policy that concentrates research funding in a narrow group of elite institutions. In the short term, this may be an efficient strategy for improving global ranking positions at the university level. The EU is concerned about the scientific brain drain from Europe to the US (Morano-Foadi, 2005). Improving ranking positions makes European institutions more attractive for scientists worldwide, to the extent that it facilitates the signaling of quality to potential employees (Bangerter et al., 2012).

In the long term, however, the strategy of boosting the performance of the elite creates unintended negative side effects, the primary one being that it 
might centralize rather than distribute economic and social development in the EU. Targeted investment in the scientific "Centres of Excellence" (MoranoFoadi, 2005) leads to the shrinking of the domestic labor market for the graduates of elite institutions who aspire to work in a research-productive environment and are, therefore, unwilling to move downward along the research-visibility hierarchy. This hinders the development of research capabilities in less productive institutions, widening the gap between the center and the periphery. ${ }^{2}$ The EU needs research champions to compete on a global market (Mangematin \& Baden-Fuller, 2008); however, distributed economic development is one of the key goals of EU regional policy. ${ }^{3}$ If one of the goals for policy makers is to create a distributed research capacity, then the policy ought to accommodate a longer-term labor market's response to the clustering of productive scientists in a small number of funded institutions.

\section{LIMITATIONS}

Our study is set within a European context, which is somewhat different from the context of the US and Canada, especially in relation to international mobility. A bibliometric study by Kamalski and Plume (2013) found that although in the EU internationally mobile researchers had higher citation impact, for the U.S. academics, internationally mobile researchers had lower impact than their peers who never left the US. This might be a consequence of international mobility being driven by different motivations, such as strategic career development for European researchers and a search for new cultural experiences for U.S. researchers. It is also possible that moving outside North America means a

\footnotetext{
${ }^{2}$ Although it is reasonable to assume that growth is not indefinite, and that at some stage, elite institutions would struggle to accommodate all worthy graduates, we noted that at a global level, population growth continues, accompanied by increased demand for higher education. We also noted that in situations of contraction of an economy, peripheral institutions often suffer more than elites. In an economic downturn, students tend to seek access to elite degrees that have the highest probability of securing them a job. When demand for existing degrees drops across the domestic market, elite institutions have more slack, enabling them to mitigate temporary losses, exploit geographic expansion, and explore new educational products and business models.

${ }^{3}$ http://ec.europa.eu/regional_policy/en/policy/what/ investment-policy/
}

more significant loss in scientific network centrality than the same mobility among European countries, because for many business school disciplines, the center of internationally visible science is located in North America. A recent study of U.S. academics employed in top business schools found that these academics were significantly more likely to move between workplaces within the US than to workplaces abroad (Ryazanova \& McNamara, 2016). In particular, the many highly productive institutions in the US offer a wealth of domestic labor market opportunities for graduates of research-visible $\mathrm{PhD}$ schools.

It is, however, possible that U.S. researchers who decided to move to Europe would find other benefits. In the majority of European business schools, academics coming from North America would have fewer constraints put on them in terms of target outlets for publication, because European schools are usually less inclined to use narrow journal lists. For example, top business schools in the US tend to use either the Financial Times list of 52 journals (Rindova, Williamson, Petkova, \& Sever, 2005) or the University Texas Dallas list of 24 journals for identifying "top journals" in which faculty should publish. In contrast, most European business schools rely on a much broader Chartered Association of Business Schools list of journals (Mingers \& Willmott, 2013), with 430 journals awarded three stars or more, which means that they publish original and well-executed research. Therefore, if a more inclusive definition of research productivity is used, downward mobility can be beneficial for growing the volume of research and alleviating the anxiety created by the pressure to publish in a narrow list of select journals.

We explored the patterns of international mobility in terms of its timing, the presence of radical step mobility, and the number of moves. Although we tested for difference between return international mobility and international mobility to a new country, and found none, we did not touch on other types of mobility patterns, such as the cultural and linguistic similarities of countries between which an academic moves. It is possible that the adjustment costs of international mobility are much higher where a foreign language creates additional barriers for settling into service and teaching roles. Further research could explore, for example, whether a mono- or multi-linguistic pattern of mobility is more conducive to the development of research-career capital and for reducing the negative effects of mobility on the speed of promotion. 
Our focus is on the role that mobility plays in achieving career outcomes. There is substantial variance in research-career capital explained by factors other than mobility, and there is a vibrant and growing corpus that engages with a wide range of such factors (e.g., Bergeron, Ostroff, Schroeder, \& Block, 2014; Gonzalez-Brambila, Veloso, \& Krackhardt, 2013; Ryazanova \& McNamara, 2016).

We focused on careers of tenured faculty. However, the number of permanent positions in business schools is declining (Richardson, Wardale, \& Lord, 2018), and an increasing number of faculty are on casual and fixed-term contracts. For us, the key insights from the study of tenured academics were the need for nuanced approach to the timing of international mobility, the impact of gender, and the different effect mobility has on research-career capital and the speed of academic promotion. It would be interesting to explore the choices and consequences of mobility for tenure-track and sessional faculty, with a particular focus on the role of gender in mobile academic gig economy careers.

\section{REFERENCES}

AACSB International. 2011. Globalization of management education. Changing international strategies, adaptive strategies, and the impact of institutions. Available from http://www.aacsb.edu/-/media/aacsb/publications/ research-reports/aacsb-globalization-of-managementeducation-task-force-report-2011.ashx?la=en. Accessed 05/04/18.

Acedo, F. J., Barroso, C., Casanueva, C., \& Galán, J. L. 2006. Co-authorship in management and organizational studies: An empirical and network analysis. Journal of Management Studies, 43: 957-983.

Aguinis, H., \& O’Boyle, E. 2014. Star performers in twenty-first century organizations. Personnel Psychology, 67: 313-350.

Aitchison, C. 2009. Writing groups for doctoral education. Studies in Higher Education, 34: 905-916.

Allison, P. D., \& Long, J. S. 1987. Interuniversity mobility of academic scientists. American Sociological Review, 52: 643-652.

Allison, P. D., \& Long, J. S. 1990. Departmental effects on scientific productivity. American Sociological Review, 55: 469-478.

Altbach, P. G. 1991. Patterns in higher education development: Toward the year 2000. Review of Higher Education, 14: 293-315.

Azoulay, P., Ganguli, I., \& Zivin, J. G. 2017. The mobility of elite life scientists: Professional and personal determinants. Research Policy, 46: 573-590.
Baden-Fuller, C., Ravazzolo, F., \& Schweizer, T. 2000. Making and measuring reputations: The research ranking of European business schools. Long Range Planning, 33: 621-650.

Bäker, A. 2015. Non-tenured post-doctoral researchers' job mobility and research output: An analysis of the role of research discipline, department size, and coauthors. Research Policy, 44: 634-650.

Baker, M. 2010. Career confidence and gendered expectations of academic promotion. Journal of Sociology (Melbourne, Vic.), 46: 317-334.

Bangerter, A., Roulin, N., \& König, C. J. 2012. Personnel selection as a signaling game. The Journal of Applied Psychology, 97: 719-738.

Baron, R. M., \& Kenny, D. A. 1986. The moderator-mediator variable distinction in social psychological research: Conceptual, strategic, and statistical considerations. Journal of Personality and Social Psychology, 51: 1173.

Baruch, Y., \& Hall, D. T. 2004. The academic career: A model for future careers in other sectors? Journal of Vocational Behavior, 64: 241-262.

Baruffaldi, S. H., \& Landoni, P. 2012. Return mobility and scientific productivity of researchers working abroad: The role of home country linkages. Research Policy, 41: 1655-1665.

Bedeian, A. G., Cavazos, D. E., Hunt, J. G., \& Jauch, L. R. 2010. Doctoral degree prestige and the academic marketplace: A study of career mobility within the management discipline. Academy of Management Learning \& Education, 9: 11-25.

Bergeron, D., Ostroff, C., Schroeder, T., \& Block, C. 2014. The dual effects of organizational citizenship behavior: Relationships to research productivity and career outcomes in academe. Human Performance, 27: 99-128.

Bloch, C., Graversen, E. K., \& Pedersen, H. S. 2015. Researcher mobility and sector career choices among doctorate holders. Research Evaluation, 24: 171180.

Børing, P., Flanagan, K., Gagliardi, D., Kaloudis, A., \& Karakasidou, A. 2015. International mobility: Findings from a survey of researchers in the EU. Science $\mathcal{E}$ Public Policy, 42: 811-826.

Boud, D., \& Lee, A. 2005. 'Peer learning' as pedagogic discourse for research education. Studies in Higher Education, 30: 501-516.

Callie, T. M., \& Cheslock, J. J. 2008. Hiring and compensation practices of business school deans. Review of Higher Education, 32: 25-49.

Cañibano, C., \& Bozeman, B. 2009. Curriculum vitae method in science policy and research evaluation: The state-of-the-art. Research Evaluation, 18: 86-94. 
Certo, S. T., Sirmon, D. G., \& Brymer, R. A. 2010. Competition and scholarly productivity in management: Investigating changes in scholarship from 1988 to 2008. Academy of Management Learning \& Education, 9: 591-606.

Corner, P. D., \& Pio, E. 2017. Supervising international students' theses and dissertations. Academy of Management Learning \& Education, 16: 23-38.

Cruz-Castro, L., \& Sanz-Menendez, L. 2010. Mobility versus job stability: Assessing tenure and productivity outcomes. Research Policy, 39: 27-38.

Dany, F., Louvel, S., \& Valette, A. 2011. Academic careers: The limits of the 'boundaryless approach' and the power of promotion scripts. Human Relations, 64: 971-996.

Day, N. E. 2011. The silent majority: Manuscript rejection and its impact on scholars. Academy of Management Learning \& Education, 10: 704-718.

De Meyer, A. 2012. Reflections on the globalization of management education. Journal of Management Development, 31: 336-345.

Debackere, K., \& Rappa, M. A. 1995. Scientists at major and minor universities: Mobility along the prestige continuum. Research Policy, 24: 137-150.

Doherty, N. 2013. Understanding the self-initiated expatriate: A review and directions for future research. International Journal of Management Reviews, 15: 447-469.

Dowd, K. O., \& Kaplan, D. M. 2005. The career life of academics: Boundaried or boundaryless? Human Relations, 58: 699-721.

Downey, S. N., Van der Werff, L., Thomas, K. M., \& Plaut, V. C. 2015. The role of diversity practices and inclusion in promoting trust and employee engagement. Journal of Applied Social Psychology, 45: 35-44.

Edler, J., Fier, H., \& Grimpe, C. 2011. International scientist mobility and the locus of knowledge and technology transfer. Research Policy, 40: 791-805.

Equeter, E., \& Hellemans, C. 2016. Influence of international mobility on the attitudes of researchers. Revue Européenne de Psychologie Appliquée. European Review of Applied Psychology, 66: 47-55.

European Commission. 2014. EU Framework program Horizon 2020 online manual. Available from ec.europa. eu/research/bitlys/h2020_associated_countries.html

Fernández-Zubieta, A., Geuna, A., \& Lawson, C. 2015. Productivity pay-offs from academic mobility: Should I stay or should I go? Industrial and Corporate Change, 25: 91-114.

Fernando, W. D. A., \& Cohen, L. 2016. Exploring career advantages of highly skilled migrants: A study of
Indian academics in the UK. International Journal of Human Resource Management, 27: 1277-1298.

Gavrilova, E. V., Ushakov, D. V., \& Yorevich, A. V. 2015. Translation of scientific experience and tacit knowledge. Sociolinguistic Studies, 9(9): 28-35.

Geiger, R. L. 1990. Organized research units-Their role in the development of university research. The Journal of Higher Education, 61: 1-19.

Geiger, R. L. 1997. Doctoral education: The short-term crisis vs. long-term challenge. The Review of Higher Education, 20: 239-251.

Gibson, J., \& McKenzie, D. 2014. Scientific mobility and knowledge networks in high emigration countries: Evidence from the Pacific. Research Policy, 43: 1486-1495.

Gonzalez-Brambila, C. N., Veloso, F. M., \& Krackhardt, D. 2013. The impact of network embeddedness on research output. Research Policy, 42: 1555-1567.

Gu, J. B., Lin, Y., Vogel, D., \& Tian, W. 2011. What are the major impact factors on research performance of young doctorate holders in science in China: A USTC survey. Higher Education, 62: 483-502.

Halevi, G., Moed, H. F., \& Bar-Ilan, J. 2016. Researchers' mobility, productivity and impact: Case of top producing authors in seven disciplines. Publishing Research Quarterly, 32: 22-37.

Harzing, A.-W., \& Alakangas, S. 2016. Google Scholar, Scopus and the Web of Science: A longitudinal and crossdisciplinary comparison. Scientometrics, 106: 787-804.

Hilmer, C. E., \& Hilmer, M. J. 2007. On the relationship between the student-advisor match and early career research productivity for agricultural and resource economics PhDs. American Journal of Agricultural Economics, 89: 162-175.

Hommel, U., \& Thomas, H. 2014. Research on business schools: Themes, conjectures, and future directions. In A. M. Pettigrew, E. Cornuel, \& U. Hommel (Eds.), The institutional development of business schools: 6-38. Oxford, UK: Oxford University Press.

Hong, W., \& Zhao, Y. D. 2016. How social networks affect scientific performance: Evidence from a national survey of Chinese scientists. Science, Technology $\mathcal{E}$ Human Values, 41: 243-273.

Horta, H. 2013. Deepening our understanding of academic inbreeding effects on research information exchange and scientific output: New insights for academic based research. Higher Education, 65: 487-510.

Horta, H., Veloso, F. M., \& Grediaga, R. 2010. Navel gazing: Academic inbreeding and scientific productivity. Management Science, 56: 414-429.

Huisman, J., de Weert, E., \& Bartelse, J. 2002. Academic careers from a European perspective: The declining 
desirability of the faculty position. The Journal of Higher Education, 73: 141-160.

Janger, J., \& Nowotny, K. 2016. Job choice in academia. Research Policy, 45: 1672-1683.

Johansson, M., \& Śliwa, M. 2014. Gender, foreignness and academia: An intersectional analysis of the experiences of foreign women academics in UK business schools. Gender, Work and Organization, 21: 18-36.

Jonkers, K., \& Cruz-Castro, L. 2013. Research upon return: The effect of international mobility on scientific ties, production and impact. Research Policy, 42: 13661377.

Kahn, S., \& MacGarvie, M. 2012. The effects of the foreign Fulbright program on knowledge creation in science and engineering. In J. Lerner \& S. Stern (Eds.), The rate and direction of inventive activity revisited: 161-197. Chicago, IL: University of Chicago Press.

Kamalski, J., \& Plume, A. 2013. Comparative benchmarking of European and US research collaboration and researcher mobility. Science Europe and Elsevier. Available from http://info.scival.com/researchinitiatives/science-europe. Accessed September 22nd, 2013.

Knights, D., \& Clarke, C. A. 2014. It's a bittersweet symphony, this life: Fragile academic selves and insecure identities at work. Organization Studies, 35: 335-357.

Lamb, M., \& Sutherland, M. 2010. The components of career capital for knowledge workers in the global economy. International Journal of Human Resource Management, 21: 295-312.

Laudel, G. 2005. Migration currents among the scientific elite. Minerva, 43: 377-395.

Lepori, B., Seeber, M., \& Bonaccorsi, A. 2015. Competition for talent. Country and organizational-level effects in the internationalization of European higher education institutions. Research Policy, 44: 789-802.

Libaers, D. P. 2007. Role and contribution of foreign-born scientists and engineers to the public US nanoscience and technology research enterprise. IEEE Transactions on Engineering Management, 54: 423-432.

Lichy, J., \& Pon, K. 2015. For better or for worse: The changing life of academic staff in French business schools. Journal of Management Development, 34: 536-552.

Lissoni, F., Mairesse, J., Montobbio, F., \& Pezzoni, M. 2011. Scientific productivity and academic promotion: A study on French and Italian physicists. Industrial and Corporate Change, 20: 253-294.

Long, J. S. 1997. Regression models for categorical and limited dependent variables. London: Thousand Oaks.
Mamiseishvili, K. 2010. Foreign-born women faculty work roles and productivity at research universities in the United States. Higher Education, 60: 139-156.

Mangematin, V., \& Baden-Fuller, C. 2008. Global contests in the production of business knowledge: Regional centres and individual business schools. Long Range Planning, 41: 117-139.

Marx, R. D., Garcia, J. E., Butterfield, D. A., Kappen, J. A., \& Baldwin, T. T. 2016. Isn't it time we did something about the lack of teaching preparation in business doctoral programs? Journal of Management Education, 40: 489-515.

McAlpine, L., Amundsen, C., \& Turner, G. 2014. Identitytrajectory: Reframing early career academic experience. British Educational Research Journal, 40: 952-969.

McFadyen, M. A., \& Cannella, A. A., Jr. 2004. Social capital and knowledge creation: Diminishing returns of the number and strength of exchange relations. Academy of Management Journal, 47: 735-746.

Mendenhall, M. E., Arnardottir, A. A., Oddou, G. R., \& Burke, L. A. 2013. Developing cross-cultural competencies in management education via cognitivebehavior therapy. Academy of Management Learning \& Education, 12: 436-451.

Miller, A. N., Taylor, S. G., \& Bedeian, A. G. 2011. Publish or perish: Academic life as management faculty live it. Career Development International, 16: 422-445.

Miller, C. C., Glick, W. H., \& Cardinal, L. B. 2005. The allocation of prestigious positions in organizational science: Accumulative advantage, sponsored mobility, and contest mobility. Journal of Organizational Behavior, 26: 489-516.

Mingers, J., \& Xu, F. 2010. The drivers of citations in management science journals. European Journal of Operational Research, 205: 422-430.

Mingers, J., \& Willmott, H. 2013. Taylorizing business school research: On the 'one best way' performative effects of journal ranking lists. Human Relations, 66: 1051-1073.

Morano-Foadi, S. 2005. Scientific mobility, career progression, and excellence in the European research area. International Migration (Geneva, Switzerland), 43: 133-162.

Oliver, E. A. 2012. Living flexibly? How Europe's science researchers manage mobility, fixed-term employment and life outside work. International Journal of $\mathbf{H u}-$ man Resource Management, 23: 3856-3871.

Ortmans, L. 2015, January 25. Methodology: FT Global MBA Ranking 2015. Financial Times. Retrieved 7 September, 2015, from http://www.ft.com/cms/s/2/75fc5c249b1d-11e4-b651-00144feabdc0.html\#axzz3giEw0nZn 
Park, S. H., \& Gordon, M. E. 1996. Publication records and tenure decisions in the field of strategic management. Strategic Management Journal, 17: 109-128.

Parker, J. 2008. Comparing research and teaching in university promotion criteria. Higher Education Quarterly, 62: 237-251.

Pazzaglia, F., Flynn, S., \& Sonpar, K. 2012. Performance implications of knowledge and competitive arousal in times of employee mobility: "The immutable law of the ex." Human Resource Management, 51: 687-707.

Pherali, T. J. 2012. Academic mobility, language, and cultural capital: The experience of transnational academics in British higher education institutions. Journal of Studies in International Education, 16: 313-333.

Phillips, E. M., \& Pugh, D. S. 2005. How to get a PhD: A handbook for students and their supervisors, (4th ed.). Maidenhead, Berkshire: Open University Press.

Plompen, M. 2013. Internationalisation strategies for business schools. Available from http://www.efmd. org/blog/view/387-internationalisation-strategies-forbusiness-schools.

Porter, L. W., Hackman, J. R., Lawler, E. E. 1975. Behavior in organizations. McGraw-Hill.

Richardson, J. 2009. Geographic flexibility in academia: A cautionary note. British Journal of Management, 20: S160-S170.

Richardson, J., Wardale, D., \& Lord, L. A. 2018. Sessional Academics Careers: Making Choices? Academy of Management Proceedings, 2018 (1).

Richardson, J., \& Zikic, J. 2007. The darker side of international academic career. Career Development International, 12: 164-186.

Rindova, V. P., Williamson, I. O., Petkova, A. P., \& Sever, J. M. 2005. Being good or being known: An empirical examination of the dimensions, antecedents, and consequences of organizational reputation. Academy of Management Journal, 48: 1033-1049.

Rodkin, J. 2014, November 10. Best business schools 2014: How they were ranked. Bloomberg Businessweek. Retrieved 7 September, 2015, from http://www. bloomberg.com/bw/articles/2014-11-10/best-businessschools-2014-methodology-for-ranking-schools.

Ryazanova, O., \& McNamara, P. 2016. Socialization and proactive behavior: Multilevel exploration of research productivity drivers in US Business Schools. Academy of Management Learning $\mathcal{E}$ Education, 15: 525-548.

Ryazanova, O., McNamara, P., \& Aguinis, H. 2017. Research performance as a quality signal in international labor markets: Visibility of business schools worldwide through a global research performance system. Journal of World Business, 52: 831-841.
Sang, K., Al-Dajani, H. , \& Özbilgin, M. 2013. Frayed careers of migrant female professors in British academia: An intersectional perspective. Gender, Work and Organization, 20: 158-171.

Schworm, S. K., Cadin, L., Carbone, V., Festing, M., Leon, E., \& Muratbekova-Touron, M. 2017. The impact of international business education on career success Evidence from Europe. European Management Journal, 35: 493-504.

Seibert, S. E., Kacmar, K. M., Kraimer, M. L., Downes, P. E., \& Noble, D. 2017. The role of research strategies and professional networks in management scholars' productivity. Journal of Management, 43: 1103-1130.

Siekierski, P., Lima, M. C., \& Borini, F. M. 2018. International mobility of academics: Brain drain and brain gain. European Management Review, 10.1111/emre.12170 .

Smeby, J. C., \& Try, S. 2005. Departmental contexts and faculty research activity in Norway. Research in Higher Education, 46: 593-619.

Storme, T., Faulconbridge, J. R., Beaverstock, J. V., Derudder, B., \& Witlox, F. 2017. Mobility and professional networks in academia: An exploration of the obligations of presence. Mobilities, 12: 405-424.

Tharenou, P. 2008. Disruptive decisions to leave home: Gender and family differences in expatriation choices. Organizational Behavior and Human Decision Processes, 105: 183-200.

Thomas, H., Lorange, P., \& Sheth, J. 2013. The business school in the twenty-first century. Cambridge University Press.

Van den Brink, M., Fruytier, B., \& Thunnissen, M. 2013. Talent management in academia: performance systems and HRM policies. Human Resource Management Journal, 23: 180-195.

Veugelers, R., \& Van Bouwel, L. 2015. The effects of international mobility on European researchers: Comparing intra-EU and US mobility. Research in Higher Education, 56: 360-377.

Wang, A. Y., \& Frederick, C. M. 2018. Leadership in higher education: Opportunities and challenges for psychologist-managers. The Psychologist Manager Journal, 21: 197-207.

Webber, K. L. 2012. Research productivity of foreign- and US-born faculty: Differences by time on task. Higher Education, 64: 709-729.

Welch, A. R. 1997. The peripatetic professor: The internationalisation of the academic profession. Higher Education, 34: 323-345.

White, C. S., James, K., Burke, L. A., \& Allen, R. S. 2012. What makes a "research star"? Factors influencing the research productivity of business faculty. International Journal of Productivity and Performance Management, 61: 584-602. 
White, K., Carvalho, T., \& Riordan, S. 2011. Gender, power and managerialism in universities. Journal of Higher Education Policy and Management, 33: 179-188.

Williamson, I. O., \& Cable, D. M. 2003. Predicting early career research productivity: The case of management faculty. Journal of Organizational Behavior, 24: 25-44.

Willmott, H. 2011. Journal list fetishism and the perversion of scholarship: Reactivity and the ABS list. Organization, 18: 429-442.

Yamashita, Y., \& Yoshinaga, D. 2014. Influence of researchers' international mobilities on publication: A comparison of highly cited and uncited papers. Scientometrics, 101: 1475-1489.

Yang, L. J., \& Webber, K. L. 2015. A decade beyond the doctorate: The influence of a US postdoctoral appointment on faculty career, productivity, and salary. Higher Education, 70: 667-687.

Zubieta, A. F. 2009. Recognition and weak ties: Is there a positive effect of postdoctoral position on academic performance and career development? Research Evaluation, 18: 105-115.
$M$

Olga Ryazanova is a lecturer of management in the School of Business at Maynooth University. She earned her PhD in strategic management from University College Dublin (Ireland). Her research focuses on microfoundations of organizational decision-making and outcomes in knowledge-intensive industries, such as academia. Olga is particularly interested in the individual and grouplevel processes that influence academic careers and academic performance.

Peter McNamara is currently the head of School of Business and a professor of management at Maynooth University. He earned his $\mathrm{PhD}$ in strategic management from City University (London), Cass Business School. His research explores the processes and performance consequences of management and career decisions upon business schools and faculty. He also researches the process and performance consequences of collaboration and innovation (including R\&D and business models).

$M$ 
Copyright of Academy of Management Learning \& Education is the property of Academy of Management and its content may not be copied or emailed to multiple sites or posted to a

listserv without the copyright holder's express written permission. However, users may print, download, or email articles for individual use. 